University of Miami Law School University of Miami School of Law Institutional Repository

2003

\title{
Foreword: Addressing the Real World of Racial Injustice in the Criminal Justice System
}

Donna Coker

University of Miami School of Law, dcoker@law.miami.edu

Follow this and additional works at: https://repository.law.miami.edu/fac_articles

Part of the Law and Race Commons, and the Law and Society Commons

\section{Recommended Citation}

Donna Coker, Foreword: Addressing the Real World of Racial Injustice in the Criminal Justice System, 93 J. Crim. L. \& Criminology 827 (2003).

This Article is brought to you for free and open access by the Faculty and Deans at University of Miami School of Law Institutional Repository. It has been accepted for inclusion in Articles by an authorized administrator of University of Miami School of Law Institutional Repository. For more information, please contact library@law.miami.edu. 


\section{SUPREME COURT REVIEW}

\section{FOREWORD: ADDRESSING THE REAL WORLD OF RACIAL INJUSTICE IN THE CRIMINAL JUSTICE SYSTEM}

\section{DONNA COKER*}

Reading Supreme Court decisions in criminal cases often feels like falling down the rabbit hole: ${ }^{1}$ a bizarre adventure where nothing is what the Court says it is and circular reasoning passes for analysis. In the Court's Fourth Amendment jurisprudence, "there is a tendency ... to pretend that the world we all know is not the world in which law enforcement operates." This is a "raceless world ... a constructed reality in which most police officers do not act on the basis of considerations of race, the facts underlying a search or seizure can be evaluated without examining the influence of race, and the applicable constitutional mandate is wholly unconcerned with race."

* Professor of Law, University of Miami School of Law. Colleagues and friends Marc Fajer and Martha Mahoney provided useful comments and insights for which I am very grateful. Charles Lanzdorf, Ana Prentice, David Gottlieb, and Natalie Barefoot provided able research assistance. Sonia Ramos, Sue Anne Campbell, and Barbara Cuadras provided administrative and librarian assistance. I am grateful for their support.

1 See Lewis Carroll, Alice's Adventures IN WONDERland Chapter One (Broadview Press Ltd. 2000). Down the Rabbit Hole begins Alice's bizarre adventures when she follows a white rabbit down the hole to a place where nothing is what it seems and nonsense can cost you your head. Id.

2 Stephen A. Saltzburg, The Supreme Court, Criminal Procedure and Judicial Integrity, 40 AM. CRIM. L. REv. 133, 133 (2003). The author continues:

[w]hether the Court is out of touch with the world in which most people live or is blinking and winking to aid law enforcement probably does not matter. Decisions that do not correspond to the world in which most people live threaten to undermine the integrity of the judicial system.

Id. at 134.

${ }^{3}$ Anthony C. Thompson, Stopping the Usual Suspects: Race and the Fourth Amendment, 74 N.Y.U. L. Rev. 956, 962 (1999). "[T]hroughout its existence, the Rehnquist Court has consistently ruled against criminal defendants and in favor of the government." Erwin 
enforcement ${ }^{4}$ and prosecutors ${ }^{5}$ is rare and individuals, without regard to their location in the racial hierarchy, are presumed to know that they may refuse a police officer's search request ${ }^{6}$ without dire consequences.

The Court's application of Equal Protection jurisprudence to criminal cases is similarly divorced from reality. As a number of scholars have noted, the Court's decision in Whren v. United States ${ }^{7}$ divorces Equal Protection analysis from the Fourth Amendment's control on police discretion. $^{8} \quad$ Further, when law enforcement officers use express distinctions based on racial categories, rather than apply the strict scrutiny

Chemerinksy, Understanding the Rehnquist Court: An Admiring Reply to Professor Merrill, 47 ST. Louis U. L.J. 659, 660 (2003).

${ }^{4}$ For example, in a Supreme Court case involving a full arrest based on a traffic violation for which incarceration was not a penalty, Justice Souter concluded that the problem of police overkill cannot be that bad because "the country is not confronting anything like an epidemic of unnecessary minor-offense arrests." Atwater v. City of Lago Vista, 532 U.S. 318,354 (2001) (concluding that "the probable-cause standard applies to all arrests, without the need to balance the interests and circumstances involved in particular situations"). As Stephen Saltzburg writes, "There well may be no epidemic of these cases, or at least not one that the Justices will see. These stops, arrests and searches will be of the young, of minorities and of many others who often will consent to a search as part of a stop." Saltzburg, supra note 2, at 157.

${ }^{5}$ See United States v. Armstrong, 517 U.S. 456, $463-64$ (1996) (noting that prosecutors retain broad discretion and "in the absence of clear evidence to the contrary, courts presume that they have properly discharged their official duties" (quoting United States v. Chemical Foundation, Inc., 272 U.S. 1, 14-15 (1926))).

${ }^{6}$ See Florida v. Bostick, 501 U.S. 429, 431 (1991) (holding that the Fourth Amendment permits officers to approach bus passengers at random to ask questions and request their consent to searches, provided a reasonable person would feel free to decline the requests or otherwise terminate the encounter); United States v. Drayton, 536 U.S. 194 (2002) (holding that bus passengers were not "seized" when law enforcement officers stood near the exit and the front entrance of the bus and a third officer leaned near a passenger and requested to search the individual's bags and person). The race of the defendants in Bostick and Drayton is not mentioned by the Court presumably because it is deemed irrelevant. See Albert W. Alschuler, Racial Profiling and the Constitution, 2002 U. CHI. LEGAL F. 163 (discussing the Court's decision in Whren v. United States, 517 U.S. 806 (1996) that bifurcates Fourth Amendment jurisprudence from Equal Protection and ignores defendants claims that they were singled out because of their race); Andrew E. Taslitz, Stories of Fourth Amendment Disrespect: From Elian to the Internment, 70 FORDHAM L. REV. 2257, 2283 (2002) ("African-American, Hispanic-American, or Asian-American communities might on average have different notions from the white community about whether an encounter with the police is voluntary or not.").

7517 U.S. $806(1996)$.

${ }^{8}$ See David Cole, No Equal Justice: Race and Class in the American Criminal JUSTICE SYSTEM 39-40 (1999); see generally Angela J. Davis, Race, Cops, and Traffic Stops, 5 U. Miami L. Rev. 425 (1997); David A. Sklansky, Traffic Stops, Minority Motorists, and the Future of the Fourth Amendment, 1997 SuP. CT. REV. 271, 326-29. 
that would apply in other settings, ${ }^{9}$ the Court has applied a reasonable suspicion test or less. ${ }^{10}$ Finally, as reiterated in the 2002-03 term decision in United States v. Bass, ${ }^{11}$ in those cases where the defendant seeks to demonstrate that despite a facially neutral category, the prosecutor brought charges or pursued heavier penalties because of his or her race, the Court's requirements make the defendant's burden of proof all but impossible to meet.

In this article I address the "real world" of criminal law enforcement. In the first section, I describe some of the overwhelming empirical evidence demonstrating unjust and unequal treatment in the criminal justice system of African Americans and, to a lesser extent, Latinos. Much of this injustice occurs as a result of America's drug enforcement policies. These policies provide the rationale for police to stop, search, and arrest, and for courts to incarcerate, disproportionate numbers of African American men and women. Drug enforcement policies are also the justification given by Attorney General John Ashcroft's Justice Department for the unequal number of African Americans charged with federal death penalty eligible crimes.

In the second section I describe the Supreme Court's response to claims of selective prosecution, that is, to claims that prosecutors sought tougher punishments for African Americans because of their race. The Supreme Court's discovery rule in United States v. Armstrong, ${ }^{12}$ reiterated again this term in Bass, ${ }^{13}$ made it practically impossible for defendants to prevail on selective prosecution claims. The Court set the standard for discovery very high: defendants must proffer evidence that "similarly situated" whites were treated more favorably. ${ }^{14}$ The Court's intent-based jurisprudence forms the familiar obstacles to claims of discrimination, but the Court's deference to prosecutors embodied in its discovery ruling in these cases makes it much more difficult to make a selective prosecution

\footnotetext{
${ }^{9}$ For a discussion of such cases, see Alschuler, supra note 6.

${ }^{10}$ See Alschuler, supra note 6, at 193-94 (describing the Supreme Court's decision in United States v. Martinez-Fuerte, 428 U.S. 543 (1976) (concluding that border detentions based on ethnic appearance "were so brief and unintrusive that 'reasonable suspicion' was unnecessary to justify them")); Martinez-Fuerte, 428 U.S. at 562 ("[T]he resulting intrusion on the interests of motorists [is] minimal[,] . . the purpose of the stops is legitimate and in the public interest[,] . . a and the need is demonstrated . . . . Accordingly, we hold that the stops and questioning at issue may be made in the absence of any individualized suspicion ....").

11536 U.S. 862 (2002).

12517 U.S. 456 (1996).

${ }^{13} 536$ U.S. at 862.

${ }^{14}$ Bass, 536 U.S. at $862 ;$ Armstrong, 517 U.S. at 465.
} 
claim than to bring claims of intentional discrimination in other contexts. The "similarly situated" data may not exist or the prosecutor may have exclusive access to the required data. In addition, the "similarly situated" standard is a wholly indeterminate standard. Courts that are hostile to selective prosecution claims can always find white comparators dissimilar.

In the third section I discuss the most prominent government rationale for race disparities in federal drug enforcement arrests and incarceration: that federal agents are focusing on violent street gangs engaged in largescale drug trafficking and these gangs are predominantly African American in membership. This explanation also figures prominently in Attorney General Ashcroft's explanation of racial disparities in the federal death penalty system. ${ }^{15}$ The validity of the government's empirical claim is undermined by research that finds that most drug offenders incarcerated in federal prisons are non-violent offenders and most are not affiliated with a criminal organization. In this section I also examine current Justice Department research regarding the causes of racial disparities in the federal death penalty system. I conclude that this research is too narrow in scope to provide the data most needed to test the government's empirical claims regarding drug offending.

The argument that African Americans are overrepresented in drug charging in federal court because they are disproportionately members of violent street gangs engaged in high volume trafficking demonstrates the ease with which the government can defeat a defendant's claim that "similarly situated" whites were treated more favorably. There is no empirical data that would prove the government's claim and the data that does exist suggests that the claim may be inaccurate. But for the defendant who must proffer evidence of white violent gang members not similarly prosecuted in federal court, the burden is nearly impossible to meet.

In the final section, I examine the potential for change in the racial operation of the criminal justice system. I argue that changes in social perceptions of crime and criminal offending have the potential to result in legislative and policy changes. Such changes require organizing in communities of color, but also require challenges to white thinking about crime. I identify three major obstacles to changes in white perceptions. First are deeply embedded racist stereotypes of black criminality and dangerousness in white perceptions of crime. Second, whites tend to understand race discrimination to mean intentional acts of a bigoted actor. This framework focuses debate on the motives of law enforcement personnel, rather than on systemic racial injustice. Third, whites are seldom

\footnotetext{
${ }^{15}$ See infra notes $137-44$ and accompanying text.
} 
aware of the degree to which white privilege protects them from police suspicion and surveillance. The invisibility of white privilege (to whites) encourages them to presume that system maltreatment is, in some part, the fault of the victim of such maltreatment. Finally, I examine the growing Innocence Movement for its potential to be a vehicle for challenging these aspects of white support for, or complacency regarding, racial disparities in the criminal justice system.

\section{THE REAL WORLD: THE IMPACT OF THE OPERATION OF THE CRIMINAL JUSTICE SYSTEM ON THE LIVES OF AFRICAN AMERICAN INDIVIDUALS}

In the domestic violence field, in which I do most of my work, we are plagued with a lack of data, particularly data on the effects of criminal justice system intervention in the lives of men, women, and children who are marginalized as a result of race, class, or immigrant status. ${ }^{16}$ In contrast, a plethora of research demonstrates the overall negative impact of current drug enforcement policies on the lives of people of color who reside in poor inner city neighborhoods. ${ }^{17}$ These policies harm both those who engage in criminal behavior as well as those who do not.

For several years official incarceration data told the shocking truth: though African Americans make up about twelve percent of the national population, ${ }^{18}$ they represent close to half of those who are incarcerated for crimes. ${ }^{19}$ An estimated twelve percent of African American men ages twenty to thirty-four were either in jail or prison in $2002 .^{20}$ This compares

${ }^{16}$ See, e.g., Donna Coker, Shifting Power for Battered Women: Law, Material Resources, and Poor Women of Color, 33 U.C. DAVIS L. REV. 1009, 1028-29 (2000) [hereinafter Coker, Shifting Power] (describing the lack of research regarding the experiences of Latinas and other women of color including those of domestic violence and the corresponding lack of information regarding the impact of law reform on the same); Donna Coker, Crime Control and Feminist Law Reform in Domestic Violence Law Reform: A Critical Review, 4 BufF. CRIM. L. REv. 801, 809-10 (2001) [hereinafter Coker, Crime Control] ("Despite evidence of disproportionate effects [of criminal intervention for domestic violence], little research has examined the impact of mandatory policies in lowincome African American and Latino communities.").

17 See infra notes 22-31 (describing disproportionate arrests, traffic stops, and incarceration resulting in harms to individuals, neighborhoods, and families).

${ }^{18}$ U.S. CENSUS BUREAU, DEP'T OF COMMERCE, CENSUS 2000, available at http://www.census.gov/population/cen2000/phc-tl/tab01/txt (internet release date April 2, 2001).

19 Paige M. Harrison \& Jennifer C. Karberg, U.S. Dep't of Justice, Prison and Jail INMATES AT MIDYEAR 2002, at 5 (2003), available at http://www.ojp.usdoj.gov/bjs/pub/ pdf/pjim02.pdf.

${ }^{20}$ Id. At year end 2001, African American males in this age range represented about ten percent of the prison population. PAIGE M. HARRISON \& ALLEN J. BECK, U.S. DEP'T OF JUSTICE, PRISONERS IN 2001, at 12 (2002), available at http:/www.ojp.usdoj.gov/bjs/pub/ 
to just $1.6 \%$ of white men in the same age group. ${ }^{21}$ Researchers with the Bureau of Justice Statistics estimate that twenty-eight percent of African American males will be jailed or imprisoned at some point in their life. ${ }^{22} \mathrm{~A}$ study conducted by the Sentencing Project reports that nearly one in three (32.2\%) African American men between the ages of twenty and twentynine are under the supervision of the criminal justice system on any given day. ${ }^{23}$

The "War on Drugs" policies that focus on supply-side enforcement against low-level dealers in inner city areas account for a significant amount of this racial disparity. ${ }^{24}$ In federal prison, the federal 100-to-1 sentencing disparity between crack cocaine and powder cocaine, ${ }^{25}$ coupled with a federal law enforcement focus on crack offenses, ${ }^{26}$ also plays a significant role in creating the disparity.

pdf/p01.pdf.

${ }^{21}$ HARRISON \& KARBERG, supra note 19 , at 5.

${ }^{22}$ Fox Butterfield, Prison Rates Among Blacks Reach A Peak, Report Finds, N.Y. TIMES Apr. 7, 2003, at A12 (quoting Allen J. Beck, chief prison demographer for the Bureau of Justice Statistics).

${ }^{23}$ The Sentencing Project, Report Summary: Young Black Americans and the CRIMINAL JUSTICE SYSTEM: FIVE YEARS LATER (2001), available at http://www.sentencingproject.org/pdfs/9070smy.pdf. Incarceration rates continue to climb. See HARRISON \& KARBERG, supra note 19, at 13.

${ }^{24}$ See, e.g., Alfred Blumstein, Racial Disproportionality of U.S. Prison Populations Revisited, 64 U. CoLO. L. REv. 743 (1993) [hereinafter Blumstein, Racial Disproportionality]; Alfred Blumstein, Incarceration Trends, 7 U. CHI. L. SCH. ROUNDTABLE 95 (2000) [hereinafter Blumstein, Incarceration Trends]. See generally MichaEL TONRY, Malign Neglect: RACE, CRIME, AND PUnishment in America (1995); Tracey L. Meares, Norms, Legitimacy and Law Enforcement, 79 OR. L. REV. 391, 396-97 (2000) [hereinafter Meares, Norms]; Jeffrey Fagan et al., Reciprocal Effects of Crime and Incarceration in New York City Neighborhoods, Fordham URB. L.J. (forthcoming 2003), Paper No. 03-54, Columbia Law School, Public Law \& Legal Theory Working Paper Group, available at http://papers.ssm.com/sol3/cf_dev/AbsByAuth.cfm?per_id=197394.

${ }^{25}$ See U.S. Sentencing Comm'n, Report to Congress: Cocaine and Federal SENTENCING, at iv-v (2002) ("[Federal] sentencing guideline range based solely on drug quantity is three to over six times longer for crack cocaine offenders with equivalent drug quantities ... [as a result] in 2000 the average sentence for a crack offense was 44 months longer than the average sentence for a powder cocaine offense, 118 months compared to 74 months."). The majority of federal and state drug offenders are incarcerated on cocaine related charges. Eric L. Sevigny \& Jonathan P. Caulkins, Kingpins or Mules: An Analysis of Drug Offenders Incarcerated in Federal and State Prisons (manuscript on file with author). The authors analyze the findings of the Survey of Inmates in State and Federal Correctional Facilities, 1997, a nationally representative survey of federal and state inmates conducted regularly by the Bureau of Justice Statistics. Id. The 1997 survey is the most currently available in a series. $I d$.

${ }^{26}$ See, e.g, Laurence A. Benner, Racial Disparity in Narcotics Search Warrants, $6 \mathrm{~J}$. GENDER RACE \& JUST. 183, 197-98 (2002). A study of drug warrants issued in San Diego 
Despite higher rates of incarceration for drug offenses, data suggests that African Americans do not use drugs any more than do whites. ${ }^{27}$ The 2001 National Household Survey on Drug Abuse found rates of illicit drug use to be $7.4 \%$ among African Americans, 7.2\% among whites, and $6.4 \%$ among Hispanics. ${ }^{28}$ Yet African Americans represent more than $57 \%{ }^{29}$ of those incarcerated for drug offenses in state prisons.

This disproportionate incarceration is not confined to African American men. The number of incarcerated African American women has also risen sharply, again primarily as a result of drug enforcement policies. ${ }^{30}$

county found that in the district which included the city of San Diego, thirty-nine percent of the warrants were for crack cocaine and only two percent of the warrant subjects for crack cocaine were white. Id. African Americans were fifty percent of the targets for crack cocaine warrants and Hispanics were forty-eight percent. Id.

${ }^{27}$ See, e.g., Blumstein, Racial Disproportionality, supra note 24; Blumstein, Incarceration Trends, supra note 24. See generally TONRY, supra note 24. Research on offending rates for interpersonal offenses suggests that African Americans have higher rates of offending than do whites. Blumstein, Racial Disproportionality, supra note 24 (finding that most of the racial disproportionality is due to differences in offending except for drug crimes). As Katheryn K. Russell notes, the degree to which racial disproportionately can not be explained by differences in offending is still cause for serious concern. See KATHERYN K. Russell, The Color of Crime: Racial hoaxes, White Fear, Black Protectionism, Police Harassment, aNd Other MiCroaggressions 31 (1998) ("By Blumstein's calculation, the 20 to 25 percent of unexplained disparity . . . represents about ten thousand Black prisoners .... Ten thousand Blacks, who may have been treated more harshly by the criminal justice system because of their race, constitutes an enormous social problem.").

${ }^{28}$ See, e.g., Substance Abuse \& Mental Health Serv. Admin. Office of Applied Studies, U.S. Dep't of Health \& HuM. Serv., 2001 National Household SuRvey on DRUG ABUSE: HIGHLIGHTS, at http://www.samhsa.gov/oas/nhsda/2k1nhsda/vol1/ highlights.htm (last accessed n.d.) [hereinafter NHSDA]. The survey reports that $7.1 \%$ of the U.S. population twelve years of age or older used an illicit drug during the month immediately prior to the survey interview. $I d$. Marijuana is by far the most commonly used illicit drug with fifty-six percent of the illicit drug users using only marijuana and an additional twenty percent using marijuana and another illicit drug. $I d$. Cocaine was used by about $0.7 \%$ of the U.S. population aged twelve or older and crack was used by only $0.2 \%$. Id. Men are more likely to report current illicit drug use than are women $(8.7 \%$ versus $5.5 \%)$. Id. Among pregnant women, only $3.7 \%$ of pregnant women ages fifteen to fortyfour reported use of illicit drugs. Id. Youth and being unemployed are highly correlated with rates of illicit drug use. While only $6.9 \%$ of fulltime employed persons reported illicit drug use, the number was $17.1 \%$ for those who were unemployed. Id. The largest percentage of users is found in the eighteen-twenty year old range. Id. College graduates had lower rates of current use $(4.3 \%)$ compared with those who completed only high school $(7.6 \%)$, even though those who had completed four years of college were more likely to report that they had tried illicit drugs in their lifetime $(47.2 \%$ versus $32.0 \%)$. Id.

${ }^{29}$ HARRISON \& BECK, supra note 20 , at 13 tbl.17. African Americans were 145,300 of the 251,100 state prisoners incarcerated for drug offenses in 2001. Id.

${ }^{30}$ See Stephanie R. Bush-Baskette, The War on Drugs as a War Against Black Women, in CRIME CONTROL AND WOMEN 113 (Susan L. Miller ed., 1998); HARRISON \& BECK, supra note 20 , at 113 (" $[D]$ rug offenders accounted for a larger portion of the growth among 
In fact, the number of women in prison is growing at a much faster rate than is true for men, ${ }^{31}$ and the largest increase is in the number of African American women. ${ }^{32}$

The interaction of drug enforcement policies and federal mandatory sentencing laws operate in a particularly pernicious way for African American women charged with drug crimes. This is true because many women convicted for drug offenses played minor roles in drug transactions for which their intimate (or former intimate) partner was a major player. ${ }^{33}$ Mandatory sentencing eliminated whatever leniency might have been afforded such women. ${ }^{34}$ In an ironic twist, because these women are such low-level players, they are often unable to provide useful information in exchange for the prosecutor's recommendation for a reduced sentence. ${ }^{35}$ The result, as Phyllis Goldfarb describes, is that they end up with longer sentences than their more culpable male co-conspirators. ${ }^{36}$

In addition to the same enforcement policies that result in disproportionately higher numbers of incarcerated African American men, the number of incarcerated African American women may be worsened by the failure of courts to recognize the impact of domestic violence in these cases. ${ }^{37}$ Duress doctrine does not usually apply to the circumstances of battered women coerced into drug offenses, and courts are often unwilling to recognize their coercion in determining sentencing. ${ }^{38}$ As Peter Margulies

female inmates (33\%) [from 1990 to 2000], compared to $19 \%$ among male offenders.").

${ }^{31}$ HARRISON \& KARBERG, supra note 19, at 5 ("[S]ince 1995 the annual rate of growth in the number of female inmates has averaged $5.4 \%$ higher than the $3.6 \%$ average increase in male inmates.").

${ }^{32}$ Id. at 13 ("Black females ... were 2.5 times more likely than Hispanic females . . . and five times more likely than white females . . to be incarcerated in 2002.").

${ }^{33}$ See Phyllis Goldfarb, Counting the Drug War's Female Casualties, 6 J. Gender RaCE \& JUST 277 (2002). Conspiracy law, with its weak actus reus requirements, makes it particularly easy for these women to be convicted of charges involving drug related conspiracies. See Joshua Dressler, Understanding Criminal LaW § 29.01 (3d ed. 2001). Because conspiracy law de-emphasizes conduct, there is a greater risk that persons will be punished for associating with others who are culpable. Id.

${ }^{34}$ See, e.g., Myrna S. Raeder, Gender and Sentencing: Single Moms, Battered Women, and Other Sex-Based Anomalies in the Gender-Free World of the Federal Sentencing Guidelines, 20 PEPP. L. REV. 905 (1993).

${ }^{35}$ Goldfarb, supra note 33, at 294.

${ }^{36}$ Id.

${ }^{37}$ Id. at 283 (describing the case of Kemba Smith, battered by her drug dealing boyfriend, was sentenced to 24.5 years on drug charges; President Clinton commuted her sentence).

${ }^{38}$ See, e.g., Peter Margulies, Battered Bargaining: Domestic Violence and Plea Negotiations in the Criminal Justice System, 11 S. CAL. Rev. L. \& WOMEN's STUD. 153 (2001); Goldfarb, supra note 33, at 294; Raeder, supra note 34, at 741-42 (describing the 
describes, defense lawyers who are unaware or unsympathetic may never learn of the abuse and prosecutors may not deem information regarding a co-defendant's abusive behavior to be material information which must be disclosed to the defense. ${ }^{39}$ This situation is likely aggravated for African American women who are viewed by courts and juries as particularly unlikely to fit the stereotype of "helpless" battered women. ${ }^{40}$

The racial disparities in incarceration likely reflect differential enforcement. Police officers are more likely to stop African Americans for traffic stops ${ }^{41}$ and, once stopped, they are more likely to search the vehicles of African Americans. ${ }^{42}$ For example, 2001 traffic stop data in San Diego found that African American drivers had a sixty percent greater chance and Hispanic drivers had a thirty-seven percent greater chance of being stopped compared to white drivers. ${ }^{43}$ Once stopped, African American drivers were more likely to have their vehicles searched. ${ }^{44}$ This increased opportunity to discover criminal offending is thought by many to be a significant reason

way in which courts have interpreted federal sentencing guidelines with regard to an abuser's coercion of a female offender).

${ }^{39}$ Margulies, supra note 38 , at 170 . Even if the abuse is exposed, courts vary in determining what role, if any, the fact of abuse should play in either conviction or sentencing. Some courts have been willing to grant downward departures for defendants who can show that they were acting under the coercion of a violent partner, while other courts have been hostile to such claims. Id. Even though federal sentencing guidelines allow courts to shorten the sentence for those who played a "minor role" in drug offenses, judges may become less inclined to allow such downward departures in appropriate cases when they find that the majority of the defendants appearing before them are minor players. As one former federal public defender told me, since all of the drug offenders in his jurisdiction fit the description of "minor role" players, courts frequently refuse to grant downward departures in appropriate cases. Interview with Ricardo Bascuas Associate Professor, University of Miami School of Law, in Coral Gables, Fla. (n.d.).

${ }^{40}$ Linda L. Ammons, Mules, Madonnas, Babies, Bath Water, Racial Imagery and Stereotypes: The African-American Woman and the Battered Woman Syndrome, 1995 WIS. L. REV. 1003, 1071 (1995) (describing the way in which racist stereotypes of African American women shape the way in which juries understand their accounts of battering).

${ }^{41}$ See, e.g., State v. Soto, 734 A.2d 350 (N.J. Super. Ct. App. Div. 1996) (expert testimony related study of New Jersey traffic stops finding disproportionate traffic stops of African American motorists); Gary Cordner, et al., Vehicle Stops in San Diego: 2001, at http://www.sannet.gov/police/pdf/stoprpt.pdf (Nov. 2002) (finding that blacks and Hispanics had a much higher likelihood of being stopped for traffic violations than did whites: one in four compared to one in ten).

${ }^{42}$ Cordner et al., supra note 41 , at 40 tbl.23 (finding that once stopped, blacks and Hispanics had a much higher chance of being searched: whites had only a $4.1 \%$ chance, blacks had a $11.1 \%$ chance, and Hispanics had $12.7 \%$ chance).

${ }^{43} \mathrm{Id}$. at 2 . The data is collected from forms that police officers are required to complete each time they stop a vehicle. Id. at 1 .

${ }^{44}$ Id. at 3. 
for the disproportionate rate of arrest and incarceration of African Americans.

Apologists of racial profiling have argued that racial profiling for African Americans is a rational and efficient use of police resources given that a larger percentage of them commit crimes than do other racial groups. ${ }^{45}$ I address the differential offending data later, ${ }^{46}$ but here it is important to note that the efficiency argument is simply inaccurate. As Professor David Harris notes, research demonstrates just the opposite: officers are less likely to find contraband or uncover other criminal behavior when they use race or ethnicity as a factor in determining whom to stop and search than if they use a non-racial focus on suspicious behavior. ${ }^{47}$ "When stops and searches are not racialized, they are more productive., ${ }^{, 48}$

An additional way in which racial disparities in arrest and incarceration for drug offenses are perpetuated is through the disparate use of search warrants. ${ }^{49}$ A study of narcotics search warrants in San Diego found racial disparities in the issuance of drug search warrants in San Diego county. ${ }^{50}$ African Americans made up only six percent of the population, but were the subjects of search warrants in twenty percent of the cases. Hispanics, who made up about twenty-four percent of the population, were search warrant subjects in forty-three percent of the cases, and whites, who were sixty-one percent of the county's population, were subjects of search warrants in only thirty-five percent of the cases. ${ }^{51}$ Most of the warrants were issued in inner city majority non-white neighborhoods, but racial disparities were true in every area of the county, even in predominantly white areas. ${ }^{52}$

${ }^{45}$ See David A. Harris, The Reality of Racial Disparity in Criminal Justice: The Significance of Data Collection, 66 LAW \& CONTEMP. PROBS. 71 (2003), available at http://www.law.duke.edu/journals/66LCPHarris (describing this commonly held view); Benner, supra note 26, at 200 (describing a veteran officer's response to racial disparities in a search warrant study, the officer told Benner, that they are simply "going where the work is").

${ }^{46}$ See discussion infra notes $172-80$ and accompanying text (questioning empirical basis of Justice Department claims that racial disparities in federal drug prosecutions are the result of the racial makeup of drug trafficking gangs); see also infra notes 217-29 and accompanying text (describing research regarding differential criminal offending).

${ }^{47}$ Harris, supra note 45 , at 82.

48 Id.

49 A confidential informant is "a source who's [sic] identity the police refuse to disclose in their probable cause affidavit." Benner, supra note 26, at 200 n.60.

${ }^{50}$ Id.

${ }^{51}$ Id. at 217 .

${ }^{52} \mathrm{Id}$. 
The evidence that supported the search warrants reveals differing enforcement tactics. With the search warrants that were issued for neighborhoods that were predominantly African American and Latino, eighty percent relied on confidential informants. ${ }^{53}$ This was not the case for warrants issued in majority-white neighborhoods. ${ }^{54}$ Confidential informants may include "drug users who have been caught and are given incentives by police to cooperate by turning in their supplier." If, as some studies have found, drug users are more likely to purchase drugs from dealers of the same race, ${ }^{56}$ one expects that the racial pattern of traffic stops and searches would increase exponentially the racial disparity in search warrants. Even if there are low rates of success, significant racial disparities in warrant issuance will likely result in race disparities in drug arrests and incarceration.

The study also found that search warrants for African American and Latino subjects were far less successful at finding drugs than were search warrants for whites. Fifty-three percent of the warrants for white subjects were successful, while the success rates for warrants that targeted Hispanics was thirty-six percent and twenty-eight percent for those that targeted African Americans. ${ }^{57}$ The racial differences remained even when the researchers controlled for the type of drug. ${ }^{58}$ It may be that, just as is true with traffic stops and searches, courts and police officers apply a lower threshold to the issuance of search warrants when the targets are African Americans or when the target resides in a "high-crime" (read non-white) ) $^{59}$ area. This would explain why warrants targeting whites are generally more successful than are those targeting African Americans and Latinos. It also suggests an additional manner in which African Americans and Latinos suffer disproportionate invasions of privacy and safety at the hands of police. $^{60}$

${ }^{53} \mathrm{Id}$. at 200.

54 Id. at 221 .

55 Id. at 201.

56 See David Rudovsky, Law Enforcement by Stereotypes and Serendipity: Racial Profiling and Stops and Searches Without Cause, 3 U. PA. J. CONST. L. 296, 309-10 (2001) (reporting on drug research).

57 Benner, supra note 26, at 263.

58 More whites were targeted for methamphetamine use and "meth labs' are more stationary and easier to find than rock [crack] cocaine," $i d$. at $220 \mathrm{n} .98$, but the racial effects remained significant even when researchers controlled for warrants targeting methamphetamines. Id. at 221 .

59 See COLE, supra note 8 , at 44. "[H]igh-crime" is code for inner city, predominantly African American or Hispanic "underclass" neighborhood. Id.

${ }^{60}$ The study author concludes: 
Racial disparities also exist in death penalty sentencing. I will focus here on federal death penalty data, which formed the basis of Bass's selective prosecution claim in Bass. The Department of Justice released a survey in 2000 and a follow-up survey in 2001 that reviewed federal death penalty cases. ${ }^{61}$ For the years $1995-2000,682$ defendants were charged with death-eligible crimes, that is crimes for which the death penalty was a potential punishment. ${ }^{62}$ The survey revealed the following data: of the 682 cases, the defendant was African American in forty-eight percent of the cases, Hispanic in twenty-nine percent of the cases, and white in only twenty percent of the cases. ${ }^{63}$ In addition, the survey found a significant racial disparity in plea bargaining. Several defendants in whose cases the Attorney General authorized a death penalty prosecution, subsequently entered a plea agreement that spared them a death penalty prosecution. ${ }^{64}$ Only twenty-five percent of African American defendants and twenty-eight percent of Hispanic defendants entered into plea agreements, compared with forty-eight percent of white defendants. ${ }^{65}$ The survey noted that there were nineteen defendants then under a federal death sentence, sixty-eight percent of whom were African American, while only twenty-one percent were white and five percent were Hispanic. ${ }^{66}$

The racial disparities in federal death penalty data were in contrast to state death penalty data. Combined state data found that fifty-five percent of defendants awaiting execution were white and forty-three percent were African American. ${ }^{67}$

The racial disparities in the federal system remained when further data was collected on cases that could have been charged with death eligible offenses, but were not. The 2001 Survey included an additional 291 cases,

\footnotetext{
do perceptions about race unconsciously color [the probable cause] determination and make [it] appear more readily when the suspect is Hispanic or black and lives in a 'high crime' area? ... The locations the police choose to patrol and what drugs they choose to target are largely a function of where they perceive 'the work is.' Those decisions are not made in isolation from the totality of our cultural beliefs, stereotypes, and perceptions.

Banner, supra note 26, at 223 (footnote omitted).

${ }^{61}$ U.S. Dep't of Justice, The Federal Death Penalty System: A Statistical Survey (19882000) (Sept. 12, 2000) available at http://www.usdoj.gov/dag/pubdoc/dpsurvey.html [hereinafter Survey 2000].

${ }^{62} I d$. at 2.

${ }^{63}$ Id. at 6.

${ }^{64}$ Id. at 32 .

${ }^{65} \mathrm{Id}$.

${ }^{66} I d$. at 36.

${ }^{67} I d$. at 36 (citing Bureau of Justice statistics data).
} 
for a total of 973 cases. $^{68}$ Of the 973 defendants who were either charged with a death-eligible offense or whose conduct was such that they could have been charged with a death-eligible offense, only seventeen percent were white, while forty-two percent were African American and thirty-six percent were Hispanic. ${ }^{69}$

The negative effects of racial disparities in arrests and incarcerations are not limited to those visited on the searched, the arrested, or the incarcerated. Rather, the impact is visited on the entire community. These community effects alone provide a compelling reason to re-examine current law enforcement policies, particularly drug enforcement policies.

When a family member is arrested, the family not only loses that person's income ${ }^{70}$ they also acquire additional expenses involved in maintaining contact with the incarcerated family member. ${ }^{71}$ Incarceration increases the burden on mothers who are left to provide for their children without the help of fathers. ${ }^{72}$

Drug enforcement concentrated in poor inner city areas populated predominantly by African Americans and other people of color means that one of the costs of long-term incarceration is deepened social disorganization in already troubled neighborhoods. ${ }^{73}$ As Tracey Meares

68 U.S. Dep't of Justice, The Federal Death Penalty System: Supplementary Data, Analysis and Revised Protocols for Capital Case Review (June 6, 2001), at http://www.usdoj.gov/dag/pubdoc/deathpenaltystudy.htm [hereinafter Survey 2001].

${ }_{69}$ Id. As I describe more fully later, the chief explanation offered by Attorney General Ashcroft for these racial disparities was that they were the result of federal law enforcement focus on violent gangs involved in drug trafficking. See infra notes 137-44 and accompanying text.

${ }^{70}$ See Ryan King, The Economics of Drug Selling: A Review of the Research, at 3 (April 2003), available at http://www.sentencingproject.org (findings of three studies on economics of drug selling confirm that most were legitimately employed and drug sales were "a complement to, rather than a substitute for, legitimate employment").

${ }^{71}$ See Marc Mauer \& Meda Chesney-Lind, Introduction to INVISIBLE PUNISHMENT: THE COLlateral CONSEQuences OF MASS IMPRISONMENT 1,3 [hereinafter INVISIBLE PUNISHMENT]. Families often cannot afford to receive calls from prison because they are required to be collect and the rates are high; families cannot afford the transportation costs of visiting someone in prison. Id. For examples of families whose finances were ruined in their efforts to seek the release of a wrongfully accused family member, see BARRY SCHECK et al., ACtual InNOCEnCE: When Justice Goes Wrong and How to MaKe it Right (2001).

${ }^{72}$ See Beth E. Richie, The Social Impact of Mass Incarceration on Women, in INVISIBLE PunishmeNT, supra note 71 , at 136, 144-47 ("[T]he already over-burdened role of caretaker ... is further complicated by the constant threat women face of possible arrest and detention of a family member....").

${ }^{73}$ Meares, Norms, supra note 24, at 396-97 ("The highest numbers of those caught under this approach will tend to be street-level dealers, who are not evenly distributed throughout a city, but who are geographically concentrated in disadvantaged, minority neighborhoods."); 
notes, "[r]emoval of these individuals in large numbers from their communities will be associated with higher levels of joblessness, low economic status, and family disruption, which in turn will disrupt the social structural and cultural determinants of community-based social control." ${ }^{, 74}$ A recent study of the effects of New York policing underscores the nature of these harms. ${ }^{75}$ The authors of the study found that incarceration in New York was concentrated in the poorest minority neighborhoods resulting in a cycle that deepens community disorganization and, ironically, increases incarceration. ${ }^{76}$ The prospects for legitimate employment diminish at the individual level as businesses refuse to hire ex-inmates, ${ }^{77}$ but the impact on employment extends to the entire neighborhood as the concentration of exinmates in an area diminishes legitimate job prospects for everyone because it "further stigmatize[s] areas and deters businesses from hiring locally or locating in such areas." ${ }^{78}$ The resulting "decrease in the number of adult males [in the community] ... weakens the general social control of children and especially adolescents" ${ }^{, 79}$ as mothers try to do it all without the money for child care and with inadequate social supports. The result is more incarceration not only because diminished legitimate employment and weakened control systems increase rates of offending, but also because "high rates of incarceration invite closer and more punitive police enforcement and parole surveillance." 80

In addition, because there are few and inadequate services for inmates in prison or for those who leave prison, incarceration may aggravate other problems. For example, while a significant number of those arrested for drug offenses report that they are drug users, addiction treatment is often not available for the incarcerated or for the newly released ex-inmate. ${ }^{81}$

Tracey L. Meares, The Increasing Significance of Genes: Reproducing Race, 92 Nw. U. L. REV. 1046, 1052 (1998) ("When traditional forms of punishment like imprisonment are concentrated on individuals from communities that are disproportionately poor, there will be predictable negative consequences-more broken families, higher levels of unemployment, general reduction of community economic well-being, and other conditions that disrupt social organization.").

${ }^{74}$ Meares, Norms, supra note 24, at 396-97.

${ }^{75}$ Fagan et al., supra note 24 , at 26.

${ }^{76} \mathrm{ld}$. at $14-15$.

${ }^{77}$ Id. at $27-28$.

${ }^{78} \mathrm{ld}$.

${ }^{79}$ Id. at 27 .

${ }^{80} \mathrm{Id}$. at 3. Thus, "[i]ncarceration begets more incarceration, and incarceration also begets more crime, which in turn invites more aggressive enforcement, which then resupplies incarceration." Id.

${ }^{81}$ Gwen Rubinstein \& Debbie Mukamal, Welfare and Housing-Denial of Benefits to Drug Offenders, in INVISIBLE PUNISHMENT, supra note 71, at 37,39. Drug treatment is not 
Experiences of prison violence coupled with the stresses of adjustment to life outside of prison may increase the risk of domestic violence, but only a few programs address this risk. ${ }^{82}$

Collateral consequences of offending also negatively affect not only the ex-felon, but the entire community. Those convicted of drug offenses may be prevented from obtaining student financial aid, ${ }^{83}$ welfare assistance for their children ${ }^{84}$ or public housing. ${ }^{85}$ Felon disenfranchisement results in a concentration of neighborhood residents who cannot vote, thus diluting the political power of the entire neighborhood. ${ }^{86}$

The concentration of incarceration and drug surveillance in a neighborhood means that residents may be less likely to seek police assistance when it is needed. A person implicated in even a small way in the drug offending of a family member or friend may fear police interaction. ${ }^{87}$ This may be a particular problem for women. There are a

widely available in the criminal justice system and the proportion of inmates receiving treatment has decreased. Id.

${ }^{82}$ See The Vera Institute, Safe Return Initiative, available at http://www.vera.org/ project/project1_1.asp?section_id=1\&project_id=27\&archive $=$ (last visited Sept. 29, 2003) (" $[\mathrm{N}] \mathrm{either}$ researchers nor practitioners have paid much attention to addressing domestic violence among African Americans as prisoners reunite with their families ...."). The Safe Return Initiative, a program of the Vera Institute and the Institute on Domestic Violence in the African American Community, engages in "community education, training, and on-site assistance" to help professionals working with ex-offenders address "domestic violence among African-Americans as prisoners reunite with their families." Id.

${ }^{83}$ See 20 U.S.C. $\S 1091$ (2000) (restricting financial aid eligibility for certain drug offenses). For a list of collateral consequences, see Gabriel J. Chin, Race, The War on Drugs, and the Collateral Consequences of Criminal Conviction, 6 J. GENDER RACE \& JUST. 253, 259 (2002). Those convicted of a felony cannot serve on federal juries, may be imprisoned for possession of a firearm, are ineligible for security clearance necessary for many jobs, cannot enlist in the military, may be excluded from public housing, and may not be eligible to be foster or adoptive parents. Id. Those convicted of a drug felony may be denied federal benefits including education benefits, may be ineligible to participate in federally-funded health care programs, may be ineligible to receive public assistance for their children, may not receive federal financial aid, and are ineligible for employment in particular federally-regulated industries. $I d$.

${ }^{84}$ See 21 U.S.C. $\S 862 \mathrm{a}$ (d)(1)(A) (2000) (requiring states to opt out of drug conviction restrictions on the receipt of Temporary Assistance to Needy Families (TANF)).

${ }^{85}$ See 24 C.F.R. $\$ 966.4$ (2003).

${ }^{86}$ Fagan et al., supra note 24 , at 28 . Approximately " 3.9 million adults are permanently disenfranchised, including 1.4 million African American men. In ten states, one-fifth or more of African American men are permanently disenfranchised." Chin, supra note 83, at $262-63$.

${ }^{87}$ See Tracey L. Meares, Place and Crime, 73 CHI.-KENT L. REV. 669, 683 (1998) ("[T]he lines between law breakers and law abiders are not so clean and clear" in inner city neighborhoods because "[m]ultiple roles are inevitable in poor, structurally weak communities where it is not uncommon for law-abiding citizens to ... rely on law breakers 
number of reasons to believe that the ranks of drug offending women overlap with the ranks of women experiencing domestic violence. Drug addicted women are likely more vulnerable to physical violence; ${ }^{88}$ some battered women report using drugs as a method of creating solidarity with their drug abusing partner; ${ }^{89}$ some women become addicted to drugs when they use them to manage pain from untreated physical injuries; ${ }^{90}$ some battered women sell drugs as a means to earn money for escape; ${ }^{91}$ and some women are coerced into assisting their partners' drug enterprise at the threat of physical harm. ${ }^{92}$ Women who need police protection may not call the police because they fear exposing their own or their partner's drug offending. ${ }^{93}$

Even when an individual has no involvement in illegal activity, interaction with law enforcement can be dangerous. Those dangers may be direct, such as the danger that police contact may result in mistreatment. Those dangers may be indirect, such as where contact with the criminal justice system invites intervention from other agents of state control,

for necessary goods such as money and security."); Richard Curtis, The Improbable Transformation of Inner-City Neighborhoods: Crime, Violence, Drugs, and Youth in the 1990 s, 88 J. CRIM. L. \& CRIMINOLOGY 1233, 1271-74 (describing those who got involved in drug dealing in order to support family members).

${ }^{88}$ See, e.g., Seth C. Kalichman et al., Sexual Coercion, Domestic Violence, and Negotiating Condom Use Among Low-Income African American Women, 7 J. WoMEN's HEALTH 371, 373 (1998). Low income African American women who experienced sexual coercion and physical violence from partner(s) were also more likely to have used illicit drugs in their last sexual encounter and were more likely to report that they were afraid to ask their male partner(s) to use condoms because they feared their abuse. Id.

${ }^{89}$ See Beth Richie, COMPELled to CRIME: THE GENDER ENTRAPMENT OF BATTERED BLACK WOMEN 123-27 (1996) (finding in interviews with battered women in prison that some developed drug dependencies while using drugs in order to establish stronger connections with their drug using, battering partners).

${ }^{90}$ See Cynthia Chandler et al., Community-Based Alternative Sentencing for HIVPositive Women in the Criminal Justice System, 14 BERKELEY WoMEN's L.J. 66, 78 (1999) (noting that some battered women become addicted through attempts to self-medicate); RICHIE, supra note 89 , at 125 (describing a woman whose abusive boyfriend brought her morphine to dull the pain from abuse).

${ }^{91}$ See RICHIE, supra note 89, at 126 (describing an interview with a white woman arrested on drug charges who sold drugs in order to finance an escape from a very violent, abusive partner).

92 See discussion supra notes 36-39 and accompanying text.

${ }^{93}$ See Coker, Crime Control, supra note 16, at 837-39. Poor women, and particularly poor African American women, suffer significant rates of domestic violence at the hands of intimate partners. See also James Ptacek, Battered Women in the Courtroom: The POWER OF JUDICIAL RESPONSES 22-24 (1999) (reviewing data from various studies and finding that domestic violence is more prevalent and more severe in low-income families); Coker, Shifting Power, supra note 15, at 1020; Richie, supra note 72, at 142 (finding that as a result of distrust in the justice system, women may not seek assistance from the system). 
notably child protection services ${ }^{94}$ and the Immigration and Naturalization Service. Children whose mothers are incarcerated often end up in state care, ${ }^{95}$ but even when mothers are not charged with criminal offending, exposing their partners' criminal offending may prompt child protection intervention. ${ }^{96}$

Finally, an additional consequence of aggressive over-policing and the concentration of incarceration in poor minority neighborhoods is the way in which police suspicion and law enforcement practice diminish the liberty and dignity accorded all members of the targeted group. ${ }^{97}$

In summary, current drug enforcement efforts that are concentrated on drug sellers in inner city racial minority neighborhoods deepen the poverty and social disorganization of these neighborhoods, thus deepening the vulnerability of residents to violence and crime. These enforcement efforts create a cycle of ever increasing incarceration. The enforcement likely increases criminal offending, heavy surveillance increases apprehension of criminal offending, and the concentration of individuals on parole or

94 See Lisa Maher \& Richard Curtis, Women on the Edge of Crime: Crack Cocaine and the Changing Contexts of Street-Level Sex Work in New York City, in CRIMINOLOGY AT THE Crossroads: Feminist Readings in CRime and Justice 100, 110 (Kathleen Daly \& Lisa Maher eds., 1998) ("The expanded interface between the criminal law and women's lives afforded by the 'war on drugs' has been accompanied by increased administrative regulation which, in labeling these women 'unfit mothers,' has sought to remove their children, their welfare and Medicaid benefits and their housing-usually in that order."). Poor women, and particularly poor African American women, are much more likely to have their children placed in foster care. See generally DOROTHY ROBERTS, SHATTERED BONDS (2002).

${ }^{95}$ Mauer \& Chesney-Lind, supra note 71, at 3. Some states make incarceration grounds for the termination of parental rights. See, e.g., FLA. STAT. ch. 39.464 (2002); Jean M. Johnson \& Christa N. Flowers, You Can Never Go Home Again: The Florida Legislature Adds Incarceration to the List of Statutory Grounds for Termination of Parental Rights, 25 FLA. ST. U. L. REV. 335 (1998).

${ }^{96}$ African American children are disproportionately represented in the foster care roles. See ROBERTS, supra note 94.

${ }^{97}$ See, e.g., Devon W. Carbado, (E)Racing the Fourth Amendment, $100 \mathrm{MICH} . \mathrm{L}$. REV. 946, 962 (2002) (describing personal experiences of police suspicion and maltreatment based on race, concluding "[o]ur privacy had been invaded, we experienced a loss of dignity, and our blackness had been established - once more-as a crime of identity."); Jerome McCristal Culp, Jr., Notes from California: Rodney King and the Race Question, 70 DENV. U. L. REV. 199, 206 (1993) ("Every time there is a conflict between the rights of the majority and my rights as a stereotypical black male, my rights cannot always be subordinate, or else $\mathrm{l}$ have no rights at all."); Patricia Williams, Spirit-Murdering the Messenger: The Discourse of Fingerpointing as the Law's Response to Racism, 42 U. MIAMI L. REV. 127, 129 (1987) (describing her rage and hurt when she was denied access to a store because of her race); RUSSELL, supra note 27 , at $44-46$ (describing the costs to the community of race-related police abuse); Taslitz, supra note 6; Alschuler, supra note 6, at 212 ("Targeting only black street gangs or only black drug dealers . . . clearly conveys the message that blacks are more to be feared than whites."). 
probation increases the range of offenses for which persons can be charged. In addition, the suspicion with which residents are treated likely results in some number of innocents charged and convicted. ${ }^{98}$

\section{THE COURT'S RESPONSE}

For the most part, criminal defendants have been unsuccessful in challenging racially disproportionate surveillance, incarceration, or application of the death penalty. ${ }^{99}$ It is old news that the Court's intentbased requirements for discrimination are seldom adequate to address the kinds of systemic discrimination that are most common. ${ }^{100}$ The Court's discovery rule in Armstrong and Bass creates obstacles for defendants that exceed those created by the need to prove discriminatory intent.

In United States v. Armstrong, ${ }^{101}$ and the recent per curiam decision in United States $v$. Bass, ${ }^{102}$ defendants moved for discovery in support of their

${ }^{98}$ For example, in the case of Timothy Brown, a mildly retarded African American individual convicted of murder and later exonerated, police focused on Brown because he was known to be a drug user who engaged in petty juvenile offenses. Interview with Brenda Bryn and Timothy Day, Federal Public Defenders in Coral Gables, Fla. (Sept. 24, 2003).

${ }^{99}$ See, e.g., McClesky v. Kemp, 481 U.S. 279, 321 (1987) (where evidence that defendants in his jurisdiction charged with killing whites were 4.3 times more likely to receive the death penalty than those charged with killing blacks and that black defendants who killed white victims had the highest chance of receiving the death penalty failed to prove discrimination in defendant's case); Whren v. United States, 488 U.S. 857 (1988) (legitimating pretextual traffic stops). For a small portion of the relevant scholarship, see CoLE, supra note 8, at 161 ("The Court has imposed nearly insurmountable barriers to persons challenging race discrimination at all stages of the criminal justice system, from policing to judging to sentencing. With the exception of jury discrimination, the barriers are so high that few claims are even filed . . ..'); Carbado, supra note 97, at 1043 (arguing that the Court's Fourth Amendment jurisprudence demonstrates a "perpetrator's perspective" that focuses on the actions of police officers when it would be preferable for the Court to adopt a "victim's perspective" that addresses the seizure question "from the perspective of a person in the defendant's position" and including the affects of race and racism in that assessment). See generally Alschuler, supra note 6 (describing the failure of the Court to fairly address claims of racial discrimination in the criminal justice system).

${ }^{100} \mathrm{~A}$ number of scholars have argued that intent-based discrimination standards are wholly inadequate to address the kind of systemic discrimination that marks much of current American society. See, e.g., Dorothy Roberts, The Priority Paradigm: Private Choices and the Limits of Equality, 57 U. PITT. L. REV. 363, 367 (1996) ("[A] central tenet of prevailing equality jurisprudence [that] human freedom requires that protection of private interests from government intrusion must supersede government promotion of equality... serves to maintain white supremacy ....."); Ruth Colker, Anti-Subordination Above All: Sex, Race, and Equal Protection, 61 N.Y.IJ. L. REV. 1003, 1005-13 (1986) (arguing that an equality framework focused on anti-subordination is superior to the Court's current focus); Mari J. Matsuda, Voices of America: Accent, Anti-Discrimination Law, and a Jurisprudence for the Last Reconstruction, 100 YALE L.J. 1329, 1392-1401 (1991).

101517 U.S. 456 (1996). 
selective prosecution claims. In Armstrong, defendants argued that federal prosecutors selectively chose to indict African Americans in federal court for crack cocaine offenses, while whites were prosecuted in state court where conviction carried much shorter sentences. ${ }^{103}$ In support of their discovery motion, defendants offered evidence that all of the twenty-four cases closed by the Federal Public Defender's office involving defendants charged with crack cocaine offenses involved African American defendants, ${ }^{104}$ that an intake counselor at a drug treatment center told defense counsel that the number of whites who use and deal drugs is equivalent to the number of racial minority persons who do so, ${ }^{105}$ and that in the experience of a seasoned criminal defense attorney, many nonblacks were prosecuted in state court for crack offenses. ${ }^{106}$

The Supreme Court ruled that to gain discovery, defendants must proffer evidence that "similarly situated" whites were treated more favorably. ${ }^{107}$ The Court then dismissed the "similarly situated" evidence proffered by the defendants. The Court explained that the testimony regarding the experiences of the drug counselor and the defense attorney were "hearsay and . . . personal conclusions based on anecdotal evidence" 108 and the study of cases handled by the federal public defender "failed to identify individuals who were not black and could have been prosecuted for [the same offense]."109

In Bass, the Court reiterated its discovery standard set forth in Armstrong and made clear that the same standard applied even when the claim was selective prosecution in electing to pursue the death penalty. ${ }^{110}$ Bass sought to prove that the federal prosecutor's decision to pursue the death penalty in his case was based on his race. His primary evidence of racial effect was the Department of Justice survey ("2000 Survey") described earlier. ${ }^{111}$ Recall that the survey found that for the years 19982000 , fifty-one percent of the defendants against whom the Department of

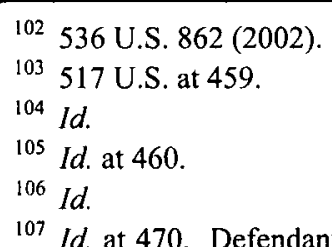
that the prosecutorial policy in question "had a discriminatory effect and ... was motivated by a discriminatory purpose." $I d$. at 465 . In order to show "discriminatory effect," defendants must show that similarly situated whites were treated more favorably. Id.

${ }^{108} I d$. at 470.

${ }^{109} \mathrm{Id}$.

110 United States v. Bass, 536 U.S. 862 (2002).

111 Survey 2000, supra note 61. 
Justice sought the death penalty were African American, compared to only twenty-five percent who were white. ${ }^{112}$ A similar disparity existed in those cases in which the Attorney General authorized death penalty prosecution but the defendant later agreed to a plea bargain. ${ }^{113}$

The Court held that Bass's evidence was inadequate to support a claim for discovery. ${ }^{114}$ With regard to the evidence that African Americans are charged in federal court more often with a death-eligible offense than are whites, the Court determined that Bass failed to demonstrate that there were "similarly situated" whites who were not so charged. ${ }^{115}$ The Court dismissed as irrelevant the racial disparities in plea bargaining because Bass was offered a plea bargain which he refused. ${ }^{116}$

\section{A. THE REALITY: CATCH-22}

"[O]ne cannot even get discovery without evidence, and one can rarely get evidence which will satisfy a court without discovery." 117

There are three problems with the Court's "similarly situated" discovery standard. First, in many cases, comparative data regarding whites may simply not exist. Thus, where the claim is that "similarly situated" whites are not arrested or charged at all, the defendant's task is impossible, absent the fortuity of social science data that examines the jurisdiction in question. ${ }^{118}$ The second problem with the "similarly situated" standard is that often, when the data does exist, it is in the exclusive control of the government. For example, imagine the situation of a capital defendant such as Bass in seeking to prove that the decision to mount a death penalty prosecution is the result of racial bias. Given the various aggravating and mitigating factors that a prosecutor might reasonably consider in determining whether to charge the death penalty, without the benefit of discovery, the defendant will not have the case information to present a meaningful assessment of whites similarly situated. Without such evidence of "similarly situated" whites, the defendant is unlikely to be granted

${ }_{112} I d$. at 23-24.

${ }^{113}$ Id.

114 Bass, 536 U.S. at 864.

115 Id. at 863-64.

116 Id. See infra note 149 and accompanying text for discussion of the reason that Bass rejected the plea bargain.

${ }^{117}$ Chin, supra note 83, at 267.

${ }^{118}$ For an excellent discussion of the difficulties with making a selective prosecution claim, given the Court's discovery ruling in Armstrong, see Richard H. McAdams, Race and Selective Prosecution: Discovering the Pitfalls of Armstrong, 73 CHI.-KENT L. REv. 605 (1998). 
discovery. ${ }^{119}$ The third problem with the Court's discovery standard is that finding "similarly situated" whites is something of a moving target. In cases such as Armstrong, where public documents may be available to show that "similarly situated" whites are treated more favorably, the Court's standard for discovery appears difficult, but not impossible. ${ }^{120}$ But, of course, whether it is merely difficult or actually impossible depends a great deal on how courts understand what it means for whites to be "similarly situated."

There are two ways in which the "similarly situated" standard becomes a moving target. First, courts hostile to selective prosecution claims may find that any white comparator is not "similarly situated." For example, in United States v. Smith, ${ }^{121}$ defendants charged with voter fraud offenses alleged that the prosecutor was motivated to charge them because of their membership in a black political organization. ${ }^{122}$ The defendants were charged with casting fraudulent absentee ballots. ${ }^{123}$ Defendants claimed that others who engaged in the same behavior, but who were affiliated with a predominantly white political organization, were not charged. ${ }^{124}$

${ }^{119}$ Indeed, there are those who argue that it is impossible to compare any two death penalty cases. Andrew McBride, former Assistant U.S. Attorney for the Eastern District of Virginia testified in a Senate Subcommittee hearing:

The Subcommittee should be very wary of the results of regression analysis or other statistical devices applied to capital punishment. No two capital defendants are the same. No two capital crimes are the same.... There are literally millions of legitimate variables that a prosecutor or jury could consider in seeking or imposing capital punishment.

Racial and Geographic Disparities in the Federal Death Penalty System: Hearing Before the Subcomm. on Constitution. Federalism and Property Rights of the Senate Comm. on the Judiciary, 105th Cong. 2 (2001) [hereinafter Senate Subcommittee Hearings] (statement of Andrew G. McBride, former Assistant U.S. Attorney, Eastern District of Virginia), available at $\mathrm{http}: / / \mathrm{www}$. senate.gov/ judiciary/oldsite/hr06130lscfp.htm.

${ }^{120}$ This was the sentiment of the majority in Armstrong:

[I]t should not have been an insuperable task to prove that persons of other races were being treated differently than respondents. For instance, respondents could have investigated whether similarly situated persons of other races were prosecuted by the State of California and were known to federal law enforcement officers, but were not prosecuted in federal court.

United States v. Armstrong, 517 U.S. 456, 470 (1996).

121231 F.3d 800 (11th Cir. 2000).

122 Id.

${ }^{123}$ The court noted that to be "similarly situated," whites not charged must have engaged in precisely the same conduct. They must have "appl[ied] for and cast[] fraudulent absentee ballots, and . . forged the voter's signature or knowingly gave false information on a ballot affidavit or application, and . . the voter whose signature those individuals signed denied voting," but also must be "similarly situated" in terms of the prosecution's case against them, "and against whom the government had evidence that was as strong as the evidence it had against Smith and Tyree." Id. at 811 .

${ }^{124} I d$. at $810-11$. 
Defendants presented evidence that individuals affiliated with the white political organization harassed voters, tried to influence someone's vote, paid people to vote, changed a vote on a ballot, and stole a ballot from a mailbox. ${ }^{125}$ The court found that this conduct was not similar to that alleged against defendants because it did not include casting fraudulent absentee ballots. ${ }^{126}$ Therefore, the comparators were not similarly situated to the defendants. Defendants also presented evidence that persons affiliated with the white political group engaged in the same conduct for which defendants were indicted-falsifying absentee ballots. The court found that these persons were not "similarly situated" because the comparators engaged in the conduct only once or twice each while one defendant was alleged to have done so seven times and a second defendant to have done so three times. ${ }^{127}$ The court did not explain why the comparator's three times was significantly dissimilar to defendant's two times.

The second way in which the "similarly situated" standard creates a moving target is that the standard recapitulates the social science debate about race and offending. ${ }^{128}$ As David Cole notes in discussing race differences in sentencing, researchers do not agree on what factors should be considered "similar" for the purpose of comparing the sentences of whites and non-whites. ${ }^{129}$ Further, even if there were agreement on what counts as similar, "no study could possibly measure all such factors.",130

\section{THE GOVERNMENT'S EXPLANATION FOR RACIAL DISPARITIES IN THE FEDERAL SYSTEM: VIOLENT DRUG-TRAFFICKING GANGS}

\section{A. THE JUSTICE DEPARTMENT'S RESPONSE TO THE RESULTS OF THE DEATH PENALTY SURVEYS}

The political discourse regarding the findings of the DOJ death penalty survey released in 2000 provides further evidence of the difficulty of pinning a reasonable meaning to the term "similarly situated." The 2000 Survey prompted an immediate response from then Attorney General Janet Reno who "directed that further study be carried out to illuminate any

125 Id. at 811 .

126 Id. at 810 .

$127 \mathrm{Id}$. at 812 .

128 See infra notes $172-80$ and accompanying text (discussing the difficulty of determining drug offending rates); see also infra notes 217-29 (describing research regarding differential racial offending).

129 COLE, supra note 8, at 150 (discussing the work of Barbara Meierhoefer).

${ }^{130} \mathrm{Id}$. 
statistical disparities at other stages of the process, such as decisions whether to pursue federal rather than state charges in potentially capital cases." 131 Reno ordered the National Institute of Justice ("NIJ") to solicit outside research proposals to conduct a study of the federal system. ${ }^{132}$ She also required U.S. Attorneys to submit summaries of all cases in which a capital eligible crime could have been charged, but was not. ${ }^{133}$

The supplemental data from the U.S. Attorneys was compiled and analyzed in a second DOJ report ("Survey 2001 ") released June 6, 2001, ${ }^{134}$ under new Attorney General John Ashcroft. Sharp racial disparities were also apparent in this sample. Survey 2001 included an additional 291 cases, for a total of 973 cases. $^{135}$ Of the 973 defendants who were either charged with a death-eligible offense or whose conduct was such that they could have been charged with a death-eligible offense, only seventeen percent were white, while forty-two percent were black and thirty-six percent were Hispanic. ${ }^{136}$

Unlike the first survey completed under Attorney General Reno's tenure, which reported data in a fairly straight forward manner with little commentary, the 2001 Survey completed after Ashcroft was appointed, was clearly an advocacy piece. ${ }^{137}$ The author of the survey argued that the racial

131 Survey 2001, supra note 68.

132 See National Institute of Justice, Strategic Planning Meeting on Research Involving the Federal Death Penalty System (January 10, 2001), available at http://www.ncjrs.org/pdffiles1/ nij/sl000490-a.pdf [hereinafter NIJ Planning Meeting] (a summary of a meeting convened by NIJ to discuss potential research to address the racial disparities found in the DOJ study). See also, Nat'l Inst. of Just., Solicitation, Research Into the Investigation and Prosecution of Homicide: Examining the Federal Death Penalty System, available at http://www.ncjrs.org/pdffiles1/nij/sl000490.pdf [hereinafter, NIJ Solicitation]. See infra pages 858-60 (discussing the NIJ studies that were subsequently funded).

${ }^{133}$ Survey 2001, supra note 68 . This included those cases where the offender's alleged conduct could have resulted in an indictment with an offense eligible for capital prosecution, but the defendant was not so charged, including where the decision not to so charge was the result of a plea bargain made before submitting the case for review. Id.

${ }^{134} 1 d$.

${ }^{135} \mathrm{Id}$.

${ }^{136} \mathrm{Id}$.

${ }^{137}$ For example, the author noted in three places that particular data does not warrant an implication of racial discrimination. Id. "Given the absence of any reason to expect a priori that racial or ethnic bias would play a role in federal capital punishment decisions, the question then becomes whether there is empirical evidence which nevertheless demonstrates that the system is subverted by such bias." Id. "The Department's follow-up study . . . produced no evidence that [the] statistical disparity results from bias or prejudice." Id. "Inferring bias from disparities [in plea bargaining] . . . would not be justified unless noninvidious causes could be excluded ...."Id. Survey 2000, by contrast, presented only the statistics. 
disparities in the pool of death-eligible cases and the resulting disparity in death penalty prosecutions were the result of individual district priorities, rather than overall trends in federal prosecution. ${ }^{138}$ The author pointed to two areas of district concern that accounted for much of the racial disparity: enforcement efforts against "violent gangs" that traffic in illicit drugs ${ }^{139}$ and inmate violence in federal prisons. ${ }^{140}$ The 2001 Survey authors provided examples from four districts, ${ }^{141}$ with the greatest part of the analysis focused on the Eastern District of Virginia. This district sent for review ${ }^{142}$ sixty-six capital cases, fifty-nine of which were for African Americans, five for whites, and two for Hispanics. ${ }^{143}$ Thus, eighty-nine percent of the defendants were African Americans, while only $7.6 \%$ were whites and about three percent were Hispanic. ${ }^{144}$ Fifty-one percent of the cases arose from federal drug enforcement task force efforts. ${ }^{145}$ The 2001 Survey author explained, "[t]he defendants in these [drug-related cases] are not White because the members of the drug gangs that engage in large-scale trafficking in the Eastern District of Virginia are not White."146

${ }^{138} \mathrm{Id}$. Facial disproportions are explained by individual district concerns: in the Eastern District of Virginia, enforcement focus on drug gangs and prison killings; the same in the District of Columbia; and killings by prison gang members in Central District of California. ld.

139 Id. Fifty-one percent of cases referred by the Eastern District of Virginia came from drug cases; all such cases involved African American or Hispanic defendants. Id. Sixty-six percent of the cases referred by the District of Columbia involved killings related to drug offending and all but one of the defendants was African American. Id.

${ }^{140}$ Id. Twenty-nine percent of the sixty-six cases referred by the Eastern District of Virginia involved killings committed by inmates at federal prison. Id. Prosecution of "Mexican Mafia" gang members for killings in California prisons accounts for some of the disproportionate number of Hispanics in Central District of California case referrals. Id.

${ }^{14 !}$ Id. (Eastern District of Virginia); Id. (District of Puerto Rico, where, not surprisingly, all cases involved Hispanic defendants); Id. (District of Columbia, where twenty-two of twenty-three cases involved African American defendants); Id. (Central District of California, where three whites, four African Americans, and six Hispanics were represented for a total of fifteen defendants).

${ }^{142}$ The policy in place required that U.S. Attorneys submit to the Office of the Attorney General for review all cases in which a defendant was charged with a capital eligible offense. The U.S. Attorneys were to provide recommendations for or against death penalty prosecution. Survey 2000 , supra note 61 , at 2 . A review committee consisting of senior Department of Justice attorneys then made a recommendation whether or not to pursue the death penalty while the Attorney General made the final decision. Id.

${ }^{143}$ Survey 200l, supra note 68.

${ }^{144} \mathrm{Id}$.

${ }^{145}$ Id. The second largest category was killings committed by inmates in federal prison (twenty-nine percent). Id. Additional cases involved kidnapping, carjacking, bank robbery, and one charge for murder in a federal enclave. $I d$.

${ }^{146}$ Id. The Survey continues, "[t]here is nothing illegitimate about a district focusing on the actual needs of the geographic area for which it is responsible in decisions about the 
In response to racial disparities in plea bargaining, the 2001 Survey author suggested that African Americans and Hispanics may be more inclined to reject a plea offer than are whites:

In contrast to a recommendation for or against seeking the death penalty, the decision about pleas is not under the control of the U.S. Attorney's office. It takes two to make a plea agreement. Inferring bias from disparities in such agreements would not be justified unless non-invidious causes could be excluded, including possible differences in the inclination of defendants from different groups to seek or accept plea bargains. ${ }^{147}$

The 2001 Survey author proffered no evidence-empirical or anecdotal-to support the claim that nearly all major drug traffickers in the Eastern District of Virginia were African American ${ }^{148}$ or that African Americans and Latinos were less likely to accept an equally attractive plea offer than were whites. ${ }^{149}$ Whether an equal number of plea offers were made to African Americans and Latinos as were made to white defendants and whether those offers were similar in both procedure and substance are questions that could be answered by Justice Department data, yet the survey contained no such data. ${ }^{150}$

exercise of federal jurisdiction," and concludes "in districts which accord a high priority to federal prosecution of violent drug gangs, that focus tends to generate a high volume of federal prosecutions involving drug-related killings." Id.

${ }^{147} I d$. The facts of Bass, however, suggest that the reasons for rejecting a plea agreement may involve prosecutorial misconduct, rather than "group" preferences. See infra note 149 (describing prosecutorial misconduct that led court to suspend plea negotiations and Bass to file a motion to dismiss).

${ }^{148}$ See supra notes 133-41 and accompanying text. As Professor Samuel Gross notes: "[h]ow does the Department of Justice know that all major drug traffickers in [the Eastern District of Virginia] - from Arlington to Norfolk to Richmond-are minorities? The report does not say. Are we supposed to accept this extraordinary statement on faith?" Senate Subcomm. Hearings, supra note 119 (testimony of Samuel R. Gross, Visiting Professor, Columbia University Law School).

${ }^{149}$ Survey 2001, supra note 68. If the facts surrounding the plea offered Bass are any indication, there may be good reason for defendants to reject plea offers. While considering a plea offer in exchange for his cooperation, Bass learned that confidential information he had provided the prosecutor had been given to another prisoner in the same detention facility in the form of an FBI interview form. Brief for Respondent in Opposition to Petition for Writ of Certiorari at 1-2 n.1, United States v. Bass, 536 U.S. 862 (2002) (No. 01-1471). The prisoner had been arrested based on the information provided by Bass. Id. According to Bass's lawyers, the breach in confidentiality prompted the trial court to refuse to proceed with the plea bargaining, and to request a formal investigation. Id. Bass filed a motion to dismiss the charges and that motion was pending at the time briefs were filed with the U.S. Supreme Court. Id at 1-2.

${ }^{150}$ See Senate Subcommittee Hearings, supra note 119 (statement of Sen. Patrick Leahy, Chairman, S. Comm. On the Judiciary). Senator Leahy notes:

[The 2001 Survey] impl[ies] that . . . minority defendants are disproportionately disinclined to 


\section{B. VIOLENT GANGS ENGAGED IN LARGE SCALE DRUG TRAFFICKING}

The argument made by the Department of Justice in the 2001 Survey is similar to the one made in Armstrong: federal agents did not intend to discriminate against African Americans; rather, the agents were focused on fighting violent drug gangs whose members happened to be African American. ${ }^{151}$ The claim is primarily about intent-that is, prosecutors were not motivated by racial animus. But the claim is also empirical: "[t]he defendants in these cases are not White because the members of the drug gangs that engage in large-scale trafficking in the Eastern District of Virginia are not White." 152

The reasoning of the Ninth Circuit in a case decided soon after Armstrong provides an example of the difficulties with the government's claims regarding the racial or ethnic makeup of drug gangs. Defendants in United States v. Turner ${ }^{153}$ made the same argument as Armstrong-that federal prosecutors chose to prosecute African American defendants for crack cocaine violations in federal court, while whites were prosecuted in state court where they faced significantly shorter sentences. ${ }^{154}$ The defendants in Turner had a significant advantage over the Armstrong defendants, however, because they had hard evidence of "similarly situated" whites who were treated more favorably. ${ }^{155}$ Criminologists Richard Berk and Alec Campbell's study of arrest and charging decisions in Los Angeles for crack cocaine offenses demonstrated that in state charging data the ratio of African Americans to whites was roughly the same as it

seek or accept plea agreements. What the report does not say is whether minority defendants are given the same opportunities to plead to non-capital charges. The Department could have investigated this question by asking its prosecutors which defendants were offered plea bargains and which were not. Apparently, this was not done.

Id.

151 Of course, by definition, those defendants whose cases were in the survey pool were accused of having committed a violent act, but Attorney General Ashcroft's argument is that drug enforcement against violent gangs produces death eligible cases against more African Americans than it does against whites (at least in the Eastern District of Virginia). If there are violent white gangs that are not targeted by federal law enforcement, than the empirical basis for the statement fails.

152 Survey 2001, supra note 68. The Survey continues, "There is nothing illegitimate about a district focusing on the actual needs of the geographic area for which it is responsible in decisions about the exercise of federal jurisdiction," and concludes "in districts which accord a high priority to federal prosecution of violent drug gangs, that focus tends to generate a high volume of federal prosecutions involving drug-related killings." Id.

153104 F.3d 1180 (9th Cir. 1997).

154 Id. at 1181-82.

$155 \mathrm{Id}$. at 1182 . 
was in state arrest data. ${ }^{156}$ However, this was not the case with federal data where forty-nine percent of the African Americans arrested for selling crack cocaine were subsequently charged, while no Anglos were so charged. ${ }^{157}$ The researchers concluded that "African Americans in general and African Americans who are charged with offenses involving cocaine base [crack] in particular are at greater risk of being charged with federal crimes than other racial/ethnic offenders." 158

The government contended that a legitimate focus on violent drug gangs explained the racial disparity in federal prosecutions. ${ }^{159}$ The Ninth Circuit found that Berk and Campbell's study did not satisfy the requirement of proving racial effect because "there [was] no showing at all that the crack cocaine sellers prosecuted by California were gang members who sold large quantities of crack; so the principal characteristic of the federal defendants [was] omitted." 160 The Ninth Circuit based its reasoning, in part, on the testimony of an FBI Special Agent that "within Los Angeles county much of the violent crime committed by street gangs . . . was connected to illegal drug trafficking." own belief that 'no single event has contributed more to the explosive growth of violent street gangs within the United States . . . than the wide availability of . . . crack . . . within American cities since the mid-to late 1980s." $" 162$

${ }^{156}$ Richard Berk \& Alec Campbell, Preliminary Data on Race \& Crack Charging Practices in Los Angeles, 6 Fed. SENTENCING REP. 36 (July/Aug. 1993). The state data showed a ratio of African Americans to Anglos arrested for crack cocaine offenses to be 3.4 to $1, i d$. at 37 , and in charging data it was a comparable 3.8 to 1 . Id . at 38 .

${ }^{157}$ Id. at 36 .

158 Id. at 38

159 See Turner, 104 F.3d at 1182-83.

$160 \mathrm{Id}$. at 1185 .

${ }^{161} I d$. at 1182 . The opinion does not indicate that the witness testified to the amount of violence committed by gang members as compared to violence committed by non-gang members, only that when gang members commit violence it is mostly drug related.

${ }^{162}$ Id. In contrast, the Federal Sentencing Commission reported that violence associated with crack cocaine distribution has diminished. UNITED STATES SENTENCING COMMISSION, Report to the Congress: Cocaine and Federal Sentencing Policy (2002) 53, n. 123 (citing Dr. Alfred Blumstein's testimony that the maturation of crack markets resulted in a national decrease in the violence associated with crack dealing). The Commission reports that the number of crack cocaine offenses in which any participant had access to a weapon went from $44.6 \%$ in 1995 to $35 \%$ in 2000 . Id. The number of crack cases in 2000 in which the offender had access to a weapon were less than $26 \%$. Id . at 54 . The number of powder or crack cocaine cases in 2000 involving threatened or actual bodily injury was less than $10 \%$. Id. at 57. However, some research indicates that gang related violence in Los Angeles continued at a high level. Cheryl L. Maxson et al., U.S. Dep't of Justice, Youth Gang Homicides in the United States in 1990, in RESPONDING TO GANGS: EVALUATION AND 
There are several problems with the Ninth Circuit's reasoning in Turner. First, whether a defendant is accused of being someone who sells "large quantities" of a drug may be, in part, an artifact of enforcement methods. As the Turner trial court noted, drug prosecutions are often the result of "sting" operations in which under cover officers make repeat buys until the target has sold a sufficient amount of drugs to warrant a lengthy sentence, if convicted. ${ }^{163}$ Therefore, even if whites charged in state court were indicted for selling smaller amounts, it would be difficult to know whether that reflected differences in offending or differences in enforcement decisions. Second, just as conspiracy law widens culpability to include a broad range of individuals whose involvement was minor, law enforcement often views membership in gangs quite broadly. ${ }^{164}$ It is difficult to know to what extent gang affiliation results from police attribution and how much from actual individual behavior. ${ }^{165}$ Further, law enforcement frequently uses race as a defining characteristic of gang membership. ${ }^{166}$ The trial court in Turner understood this:

RESEARCH, National Institute of Justice, 107, 125 (2002) (while gang related homicides went down nationally, they continued to be very high in Los Angeles and Chicago).

${ }^{163}$ United States v. Turner, 901 F. Supp. 1491, 1492 (C.D. Cal. 1995). See Blumstein, supra note 24, at 99 ("Drug offenses are profoundly discretionary in terms of who gets arrested, where police patrol, and in the aggressiveness of police, prosecution, and sentencing policy that is targeted at drug offenders.").

${ }^{164}$ For example, a 1992 report prepared by the District Attorney's staff in Los Angeles reported that forty-seven percent of black men between twenty-one and twenty-four were in police gang databases. Sheryl Stolberg, 150,000 are in Gangs, Report by D.A. Claims, L.A. TIMES, May 22, 1992, at A1. In response to criticism for this gross over-characterization, the District Attomey noted, "That number may be artificially high ... [b]ut on the other hand it may not be .... It may mean just what it says, that about one out of every two young black males are involved in gangs." Id.

${ }^{165}$ For example, some survey data relied upon by the DOJ to determine the number of gangs asks law enforcement personnel to provide information on gangs in their jurisdiction, defining "gang" to be "a group of youths in your jurisdiction that you or other responsible persons in your agency or community are willing to identify or classify as a "gang."' Maxson et al., supra note 162, at 119 (discussing The National Youth Gang Center Surveys). While an abundance of evidence exists that youth (mostly) organizations exist in inner city neighborhoods and that many of these organizations engage in criminal behavior, among other activities, there may yet be a sense in which law enforcement engages in "subject creation" of the kind described by Bernard Harcourt in his review of James Q. Wilson \& George L. Kelling's "Broken Windows" thesis. See Bernard E. Harcourt, Reflecting on the Subject: A Critique of the Social Influence Conception of Deterrence, the Broken Windows Theory, 97 MICH. L. REV. 291, 371-80 (1998).

${ }^{166}$ See, e.g., Margaret M. Russell, Entering Great America: Reflections on Race and the Convergence of Progressive Legal Theory and Practice, 43 HASTINGS L.J. 749, 759-61 (1992) (describing the use by law enforcement and private agencies of "gang profiles" that render young men of color suspect and subject to punitive sanctions and eviction from private amusement parks). 
If these defendants had been white persons engaged in the same criminal activities, they would not have been suspected of any gang association, they would not have been stung by the government to increase the penalty for the offense, and they would not have been selected by the U.S. Attorney for prosecution. They would not be here today. Their real offense is alleged gang association, not the crack offenses with which they are charged. ${ }^{167}$

When race is a characteristic used to profile a "gang" member, it is hardly surprising that law enforcement focused on gang members results in the prosecution of disproportionately high numbers of those whose race is used to define the category. Chicago's experience with its anti-gang ordinance is instructive. The ordinance, which was subsequently deemed unconstitutional by the Supreme Court, ${ }^{168}$ provided that police could order persons to disperse if the individuals were in a public place with "no apparent purpose" and if the police reasonably believed that one of the parties was a gang member. ${ }^{169}$ In the three years the ordinance was in effect, police issued over 89,000 orders to disperse and arrested more than 42,000 persons for failure to obey those orders. ${ }^{170}$ In 89,000 cases, police officers "reasonably believed" that they were interacting with a gang member. As Dorothy Roberts noted, "[p]olice not only believe that most gang members belong to minority groups; they also believe that many, if not most, inner-city minority youth are gang members." ${ }^{171}$

None of this is intended to suggest that gang related violence is not real, ${ }^{172}$ or that some of that violence is not drug-related, or that gang violence has not had devastating consequences in inner city neighborhoods. Gang violence can be real and, simultaneously, the government's enforcement tactics and a priori categories of offenders can affect the race disparities in targets for enforcement. ${ }^{173}$

\footnotetext{
${ }^{167}$ Turner, 901 F. Supp. at 1501.

${ }^{168}$ City of Chicago v. Morales, 527 U.S. 41, 64 (1999).

${ }^{169}$ Id. at 46.

${ }^{170}$ Id. at 47.

171 Dorothy E. Roberts, Foreword: Race, Vagueness, and the Social Meaning of OrderMaintenance Policing, 89 J. CRIM. L. \& CRIMINOLOGY 775, 786 (1999).

172 See Curtis, supra note 87, at 1250-51 (explaining that some drug markets in Chicago "earned reputation for controlling violence" while "distributors [in another area] ... employed it regularly and systematically"). Some research suggests that a significant amount of gang-related violence is not drug related, however. See Anthony A. Braga \& David M. Kennedy, Reducing Gang Violence in Boston, in RESPONDING TO GANGS: EVALUATION AND RESEARCH, supra note 162, at 265, 272 (a study of gang-related homicides in Boston found that most were "personal and vendetta-like" rather than "about drugs, money, or other issues").

${ }^{173}$ See generally Harcourt, supra note 165 (describing the affect of subject creation in the manner in which order maintenance policing creates "the disorderly").
} 


\section{EMPIRICAL RESEARCH REGARDING DRUG DISTRIBUTION}

As noted earlier, the National Household Survey on Drug Abuse, ${ }^{174}$ based on a random sample study of household drug use, found that similar percentages of whites and African Americans use drugs. ${ }^{175}$ Of course, the operative question for the claim made by the Justice Department in Turner and in the 2001 Survey is whether those similarities exist in data regarding drug sales. I spoke to leading drug researchers in the country about this question. ${ }^{176}$ They all said the same thing: it is impossible to tell. ${ }^{177}$ It is difficult to know the extent to which racial differences in the arrest and incarceration rates for different drugs reflect law enforcement patterns rather than drug distribution patterns. ${ }^{178}$

Despite the difficulty in assessment, there are several factors that bring into question the government's view on offending differences. Data on those incarcerated for drug crimes (both state and federal) demonstrate that the overwhelming majority are not violent offenders. ${ }^{179}$ Most reported that they neither received a sentencing enhancement for use of a firearm related to a drug offense, nor had they "ever been armed with a gun while committing a crime." 180 A recent analysis of prisoner survey data conducted by Eric Sevigny and Jonathan Caulkins found that most federal

${ }^{174}$ See NHSDA, supra note 28.

$175 / d$. (describing drug use data).

${ }^{176}$ Christine Crossland, social science analyst with the National Institute of Justice, recommended that I address my query to four "well-respected researchers in the area of drugs and crime" who are Professor Jonathan Caulkins, Carnegie Mellon University, Professor John Eck, University of Cincinnati, Martin Iguchi, RAND Corporation, and Sheigla Murphy, Institute for Scientific Analysis. E-mail from Christine Crossland, Social Science Analyst, National Institute of Justice, to Donna Coker, Professor of Law, University of Miami School of Law (July 15, 2003, 11:25 EST) (on file with author).

177 See e-mail from John Eck, Professor, University of Cincinnati, to Donna Coker, Professor of Law, University of Miami School of Law (July 15, 2003, 20:33 EST) (on file with author) ("we have no systematic data on who deals drugs untainted by police agency record keeping" though experience as an evaluation director for a regional drug enforcement group was that the focus was on the most violent groups and enforcement was "highly sensitive to the use of informants"); e-mail from Jonathan Caulkins, Professor, Carnegie Mellon University, to Donna Coker, Professor of Law, University of Miami School of Law (July 15, 2003, 16:48 EST) (on file with author) ("I think there is no scientifically valid way to assess racial or ethnic distribution of drug sellers. Hence, one cannot assess scientifically disproportionately in imprisonment for drug-law violations."); e-mail from Sheigla Murphy, Director, Center for Substance Abuse Studies, to Donna Coker, Professor of Law, University of Miami School of Law (July 17, 2003, 14:16 EST) (on file with author) (all of the relevant information she has located thus far is based on arrest record data).

${ }^{178}$ E-mail from Caulkins, supra note 177.

179 Sevigny \& Caulkins, supra note 25.

${ }^{180} \mathrm{Id}$. at 31 (quoting from survey questionnaire). 
and state prisoners incarcerated for drug offenses did not have prior convictions for violent crimes. ${ }^{181}$ Further, most incarcerated drug offenders were not part of an organized drug group: $85.7 \%$ of federal drug offenders and $91.9 \%$ of state drug offenders were not part of an organized drug group. ${ }^{182}$ While this raises questions for the government's explanation, it again does not disprove the claim. It could be that those involved in violent gang activity are prosecuted for separate violent crimes and, therefore, do not show up in the numbers of those incarcerated for drug crimes. Such an explanation would be consistent with the Justice Department's explanation of race disparities in the death penalty data, but would seem somewhat contrary to the government's argument in Armstrong and Turner. In those cases, the federal government argued that racial disparities in indictments for drug offending were the product of racial differences in membership in violent drug gangs.

What is tremendously troubling is that, unlike the elements of a charge, the decision to define some sellers as gang members, some organizations as gangs, and to ascribe the violent behavior of some gang members to that of others is wholly within the discretion of the prosecutor, not subject to proof requirements, and because of Supreme Court jurisprudence, not subject to meaningful judicial review.

\section{NIJ STUDY PROPOSAL}

Recall that former Attorney General Reno instructed the NIJ, the research arm of the DOJ, to conduct a study, using outside researchers, to examine the racial disparities in the federal death penalty system. Despite Ashcroft's assurances in his nomination hearing that he supported the NIJ study, the language of the 2001 Survey expressed reservations about the value of such a study. Describing a meeting organized by NIJ to discuss such a study, the 2001 Survey author concludes, "[such a study] would entail a highly complex, multi-year research initiative .... [that if] carried out ... could not be expected to yield definitive answers . . .",183

\footnotetext{
${ }^{181}$ Id. at 21.

${ }^{182}$ Id. at 18 . Though most drug offenders were not involved in an organized distribution gang, they were nonetheless engaged in some drug distribution. Id. at 17-18 ("less than [nine percent] of all drug inmates and only about one-half of [one percent] of federal drug inmates were convicted of simple drug possession and described themselves as user/possessor of quantities suitable for personal consumption"). And while most offenders were not members of a gang, there were differences between federal and state inmate data: more high-level importers, manufacturer/growers, money launderers, wholesale dealers, and body guard/debt collectors were found in federal prison than were found in state prison $(38.9 \%$ versus $23.9 \%)$. Id. at 17 .

${ }^{183}$ Survey 2001, supra note 68 , at 9 . This summary of the meeting discussion was
} 
Subsequent to Senate Subcommittee hearings in which (then) majority Democratic Senators chastised General Ashcroft for his failure to pursue the study, ${ }^{184}$ NIJ made a solicitation for research proposals. ${ }^{185}$ The proposals were to address the following questions:

What are the characteristics of homicide cases and offenders indicted in State systems as compared to those indicted in the Federal system?

What is the role of Federal law enforcement and its interaction with local and State law enforcement in these cases?

What are the significant decision-making factors that determine whether a case is prosecuted in the Federal or State system and whether a capital offense is charged?

What are the significant geographic, case, or other factors that help explain the resulting distribution of homicide cases prosecuted in the Federal and State systems and indicted on capital or noncapital charges? ${ }^{186}$

Eventually, two research proposals were funded. ${ }^{187}$ The focus of these research projects is far narrower than the one originally proposed in the solicitation. ${ }^{188}$ One project is a statistical study that will examine DOJ file summaries of all the death-eligible cases reported to the Attorney General's office by State Attorneys. ${ }^{189}$ The researchers will examine different variables to determine whether there is a significant correlation with the decision of the State Attorney, the Attorney General's Review Committee, or the Attorney General to seek the death penalty. ${ }^{190}$

challenged by David Bruck of the Federal Death Penalty Resource Counsel, who was also present at the meeting. See testimony of David Bruck, Senate Subcommittee Hearings, supra note 119, at 4 . Indeed, the NIJ posting of the meeting summary suggests that participants identified a range of research questions, some of which would require multi-year research, but not all. See NIJ Planning Meeting, supra note 132, at 4 (stating that some participants suggested the use of a comprehensive prospective study analyzing homicide cases from beginning to end).

184 See Senate Subcommittee Hearings, supra note 119.

${ }^{185}$ NIJ solicitation, supra note 132.

${ }^{186} \mathrm{Id}$. at 7.

${ }^{187}$ Telephone interview with Christopher Innes, Chief Justice Systems Research Division (n.d.) (notes on file with author).

${ }^{188}$ One researcher notes that the original solicitation was very broad and would have been very costly to pursue, thus responders proposed more narrow projects. Telephone Interview with Candace Johnson, Researcher, Justice Systems, Inc. (August 30, 2003) (notes on file with author).

189 Telephone Interview with Stephen Klein, Senior Research Scientist, RAND (July 21, 2003) (notes on file with author); e-mail from Richard Berk, Professor, UCLA Dep't of Statistics, to Donna Coker, Professor of Law, University of Miami School of Law (July 22, 2003, 16:22 EST) (notes on file with author).

${ }^{190}$ See Klein Interview, supra note 189. Stephen Klein and Richard Berk with are 
The second project is a qualitative analysis of data from ten federal districts. ${ }^{191}$ The researchers will interview federal and local law enforcement personnel, U.S. Attorneys, and some defense counsel regarding the decision making that led to the federal prosecution of a homicide case. ${ }^{192}$ Researchers have examined case files of death-eligible federal cases and are thinking of creating scenarios for law enforcement officers and prosecutors that match the most common scenarios in case files. The questions will regard the decision to prosecute the case federally rather than leave it to the state to prosecute. Preliminarily, researchers are finding that many of the homicide cases that come into the federal system are the results of ongoing federal investigations. ${ }^{193}$ They are also finding significant differences between federal districts in terms of decisions to prosecute homicides. ${ }^{194}$

In combination, the two research projects will examine both decisions made after a case becomes a federal case as well as information related to the decision to bring a federal indictment, rather than allow a state to bring a charge. Thus, theoretically, the combination of the projects can investigate the question about race-based decision making that is central to the claims in cases such as Bass, Armstrong, and Turner: did federal prosecutors selectively choose to prosecute African American defendants.

Despite this attention to both entry into the federal system and prosecutorial decision-making after entry, the two projects have serious limitations. First, both research projects are heavily dependent on information from the DOJ. The statistical project will rarely have access to case information that is not filtered first by the U.S. Attorney's office that generated the report summaries. ${ }^{195}$ Second, it appears that the quantitative analysis will be limited to those cases where the defendant was charged with a death-eligible crime, ${ }^{196}$ thus eliminating the ability to compare those cases with those that could have been charged with a death eligible offense, but were not. Third, though the qualitative research will examine entry into the federal system, because there is no state data for comparison, researchers can do little more than record what federal prosecutors say they do in selecting cases. This means that the research will be of little help in

\footnotetext{
working together to determine what variables should be used. Id.

191 Johnson Interview, supra note 188.

${ }^{192}$ Id.

${ }^{193} \mathrm{Id}$.

194 Id.

${ }^{195}$ Klein Interview, supra note 189. A few files will have letters from defense counsel arguing against a decision to seek the death penalty. $I d$.

${ }^{196}$ Berk e-mail, supra note 189.
} 
answering allegations, for example, that federal prosecutors chose to bring cases against African Americans in federal court because federal jury pools are predominantly white while jury pools in state courts have larger African American populations. ${ }^{197}$ Finally, by focusing exclusively on prosecutorial decision making, the research fails to gain information on the importance of differential policing and decision making prior to charging. ${ }^{198}$

\section{Challenging Racial InJustice in the CRiminal Justice System}

The Supreme Court's intentional discrimination standard is wholly inadequate to address most of the racial disparity in the criminal justice system, but the Court's additional requirement for discovery turns a slender possibility into a farce. The result is a particularly inadequate safeguard against injustice given the extraordinary power of prosecutors in this age of mandatory minimums, sentence enhancements, sentencing guidelines, and increased involvement in targeting enforcement. ${ }^{199}$ In combination with the

${ }^{197}$ As David Bruck, attorney for the Federal Death Penalty Resource Counsel, noted in testimony before the Senate Subcommittee:

[O]ne issue that bears serious study ... [is] the fact that removing a murder case from state to federal court can mean the virtual exclusion of nonwhite decision-makers from the process. In many urban jurisdictions ... African-American defendants charged in state courts are likely to be tried by majority-black juries. However, prosecutors can draw an all-white or almost allwhite jury by the simple expedient of indicting the case in federal court instead. ... If conscious racial considerations do enter federal death penalty decision-making at all, they are much more likely to appear in such ways as these, rather than as the straw man of explicit racial "favoritism" that the Department of Justice seeks to dispel in its June 6 [Survey 2001] release.

Testimony of David I. Bruck, Senate Subcommittee Hearings, supra note 119, at 7 n.3. For a description of the work of the Federal Death Penalty Resource Center, see http://www.capdefnet.org/fdprc/fdprc_gateway.htmp (last accessed n.d.).

${ }^{198}$ Researchers involved in the qualitative analysis report that preliminarily it appears that many federal homicide cases arise from large scale investigations, some involving federal-state task forces. Johnson Interview, supra 188. If this turns out to be the case, it is consistent with the explanation offered by Ashcroft's Justice Department: most of the federal homicide cases arose from drug enforcement efforts involving state-federal task forces. This fact only highlights the importance of examining the entire drug enforcement effort to determine both how individuals are targeted as well as how they are prosecuted. See Alschuler, supra note 6, at 205 ("[T] prosecutors ... was divorced from the realities of the criminal justice system. . . The practice that in fact produced the racial disparity in Armstrong - differential targeting by law enforcement-was off the Supreme Court's screen.").

199 See, e.g., Jonathan Simon, Governing Through Crime: The War on Crime and THE TRANSFORMATION OF AMERICAN GovernanCE, 1960-2000 (forthcoming 2003) (manuscript at 10)

The hardening of criminal sanctions that began in the $1980 \mathrm{~s} .$. has expanded the classic power of the prosecutor .... The formal length of sentence is probably less important than the limitation, in many states and the federal system, of a substantial role for 'administrative' release mechanisms like parole boards .... The growth of extreme sentences with no possibility of 
Court's decisions in McClesky ${ }^{200}$ and Whren, ${ }^{201}$ the result is to effectively close the court house door to claims of racial discrimination in the criminal justice system, ${ }^{202}$ except in the narrow case of jury selection. ${ }^{203}$

Proposals for federal legislation that would address racial disparities in the criminal justice system have thus far been unsuccessful. The Racial Justice $\mathrm{Act}^{204}$ would allow capital defendants to support a claim of racial discrimination in the operation of the death penalty by showing a consistent pattern of racially discriminatory death sentences in the sentencing jurisdiction. ${ }^{205}$ The proposed legislation has passed the House of Representatives twice, but both times was dropped in conference with the Senate. ${ }^{206}$ The Traffic Stops Statistics Act, ${ }^{207}$ which would require police officers to record data regarding traffic stops including the race of the

parole also deepens the significance of the prosecutor's charging role. By charging a suspect with any of the many forms of special enhancement crimes like using a gun during the primary offense, or having a previous serious or violent conviction, the prosecutor today can effectively eliminate a person from the community for a generation.

Id.; see generally Angela J. Davis, The American Prosecutor: Independence, Power, and the Threat of Tyranny, 86 IowA L. REV. 393 (2001) (describing the extraordinary powers of prosecutors); see Deborah Lamm Weisel, The Evolution of Street Gangs: An Examination of Form and Variation, in RESPONDING TO GANGS, supra note 162, at 42 (describing the way in which prosecutors working with the FBI sometimes use an "Enterprise Theory of Investigation" in which "the prosecution is structured from the inception of the investigation"').

200 McClesky v. Kemp, 481 U.S. 279, 321 (1987).

201 See supra notes 7-8 and accompanying text (discussing the Court's decision in Whren). David Cole concludes that the Supreme Court "has immunized a wide range of law enforcement from any Fourth Amendment review." COLE, supra note 8, at 53.

${ }^{202}$ COLE, supra note 8 , at 139 . Cole notes that if the role of the Court is to protect the despised minority from majoritarian politics, one can hardly think of a more classic case than African American criminal defendants. Id. He concludes that "[l]egislators have little interest in protecting the rights of accused criminals. So if the judiciary doesn't protect them, nobody will." Id.

${ }^{203}$ Batson v. Kentucky, 476 U.S. 79 (1986) (holding that Equal Protection forbids a prosecutor from challenging potential jurors solely on account of their race and establishing a method of proving such discrimination).

${ }^{204}$ See Don Edwards \& John Conyers, Jr., The Racial Justice Act-A Simple Matter of Justice, 20 U. DAYTON L. REv. 699, 699 (1995) (describing legislative efforts to pass the Act and the failure of Congress to enact the legislation). The Racial Justice Act would allow defendants to support a claim of racial discrimination in the operation of the death penalty by showing a consistent pattern of racially discriminatory death sentences in the sentencing jurisdiction. Id. at 700. See also the Traffic Stops Statistics Act, H.R. 1443, 106th Cong. (1999), and the Innocence Protection Act, H.R. 912, 107th Cong. (2001).

${ }^{205}$ Edwards \& Conyers, supra note 204, at 704.

${ }^{206} \mathrm{Id}$. at $700-01$.

207 Traffic Stops Statistics Study Act of 1999, H.R. 1443, 106th Cong. (1999). 
driver, ${ }^{208}$ has yet to be enacted. ${ }^{209}$ The Innocence Protection Act (IPA), ${ }^{210}$ while not specifically focused on racial disparities, would provide greater access to DNA testing in federal post-conviction cases, and funding to states for DNA testing and for competent counsel for indigent defendants in capital cases. ${ }^{211}$

The political discourse regarding racial disparities in the criminal justice system has largely focused on intentional discrimination committed by actors motivated by racial bias. ${ }^{212} \mathrm{~A}$ focus on bad actors and racial motives obscures the bigger picture of a system that systematically and disproportionately burdens communities of color with the excesses of law enforcement without many of the benefits.

There are better ways to understand discrimination in the criminal justice system than to search for the bad actor. One such way would be to assess the overall impact of criminal justice policies on the well-being of

$208 I d$.

209 David Harris notes, that despite the defeat of the Traffic Stops Statistics Study Act, many jurisdictions began collecting such statistics and a number of states passed legislation that mandated such data collection. David Harris, The Reality of Racial Disparity in Criminal Justice: The Significance of Data Collection, 66 LAW \& CONTEMP. PROBS. 71, 82 (2003).

${ }^{210}$ Advancing Justice Through DNA Technology Act of 2003, S. 1700, 108th Cong., First Sess., Title III (the Innocence Protection Act) (2003) [hereinafter the Innocence Protection Act]. See also Patrick Leahy, Symposium: Serenity Now or Insanity Later?: The Impact of Post-Conviction DNA Testing on the Criminal Justice System: 35 NEW ENG. L. REV. 605, 606 (2001) (describing the purposes of an early version of the Innocence Protection Act).

211 The Innocence Protection Act, supra note 210 , at $\$ \S 311-12,321$.

212 For example, Attorney General Ashcroft's defense of the racial disparities in the federal death eligible cases focused entirely on defeating charges of bad actors who acted with racial malice. Aschroft describes racial unfairness in terms of "favoritism towards white defendants," Survey 2001, supra note 68, at 11 , and discrimination to mean that prosecutors had a "particular desire to secure the death penalty for minority defendants." $I d$. at 17. As Professor David Baldus notes in his criticisms of Ashcroft's response, "No one with an understanding of the system suggests that it is driven by such conscious and blatant animus against minority defendants . . .." Statement of David C. Baldus, Memo to the Honorable Russell D. Feingold (June 11, 2001), available at http://deathpenaltyinfo.org/ article.php?scid=18\&did=252 (regarding DOJ report on the Federal Death Penalty System (June 6, 2001)). Prompted by the 2000 and 2001 DOJ Survey findings, the Senate Judiciary committee held hearings on June 13, 2001 to hear testimony regarding the "racial and geographic disparities in the federal death penalty system." Racial and Geographic Disparities in the Federal Death Penalty System: Hearing Before the Senate Comm. On the Judiciary, Subcomm. On the Constitution, Federalism and Property Rights, 107th Cong. (2001), available at http:/www.senate.gov/ judiciary/oldsite/hr06130lscfp.htm (last accessed October 15, 2003). 
communities of color, particularly African American communities who are so frequently targeted by law enforcement efforts. ${ }^{213}$

\section{A. CHANGING WHITE PERCEPTIONS}

Mobilizing communities to protest the racial injustice of the system, working to change popular consciousness and therefore state law, may offer more promise in the current political climate than either federal legislation or litigation. ${ }^{214}$ This kind of political mobilization requires, in part, addressing white misperceptions about crime and the criminal justice response to crime. ${ }^{215}$ These white perceptions involve, in large measure,

${ }^{213}$ See Roberts, supra note 171, at 835 (arguing that law enforcement policies can be evaluated "on whether they further racial subordination or help to eradicate it"). Department of Justice supporters argued in Senate subcommittee hearings in response to racial disparities in federal death penalty data, as have others, that focusing drug enforcement efforts in inner city neighborhoods means providing greater protection for the residents of those communities. See Senate Subcommittee Hearings, statement of McBride, supra note 119. No one can disagree that this is critically important. African Americans are disproportionately victims of violent crime. BUREAU OF JUSTICE STATISTICS, U.S. DEP'T OF JUSTICE, CRIMINAL Victimization IN THE UnITEd STATES, 2001 Statistical Tables, National Crime Victimization Surveys, tbl.5 (2003) available at http://www.ojp.usdoj.gov/bjs/ pdf/cvusolol.pdf (for all personal crimes, the rate of African American victims per 1000 persons age twelve or over was thirty-two, compared to a rate of 25.3 for whites and 19.9 for "other" groups). Yet, if the argument for concentrated enforcement is to rest on community needs for protection, then the government should prove the case that the benefits of its current drug enforcement efforts outweigh the harms visited on the same community. This it has failed to do.

${ }^{214}$ Some state leaders have initiated reforms that may reduce the worst effects of racial injustice in the criminal justice system. For example, officials in some states have argued publicly for alternatives to incarceration for drug offenders and other nonviolent offenders. See, e.g., Andy Paras, Chief Urges Reform of Sentencing, GREENVILLE NEws, Aug. 4, 2003, at 14A, available at http://greenvilleonline,com $/$ news $/ 2003 / 08 / 04 / 2003080411422 . \mathrm{htm}$ (director of state Department of Corrections urges state to reduce prison population by finding alternatives to incarceration for nonviolent offenders). More than fifteen states now require police to collect and report race statistics on traffic stops, and several police departments have voluntarily agreed to gather and publish such data. See Harris, supra note 45, at 82. The state of Kentucky passed the Kentucky Racial Justice Act which allows the admissibility of statistical evidence to prove that race was the basis of a death penalty decision. Ky. Rev. Stat. ANN. $\$ 532.300$ (Michie 1998). Drug courts which focus on rehabilitation rather than punishment for low-level offenders are now well-established and some areas have focused drug enforcement efforts on sellers rather than buyers, thus diminishing the affects of concentrated incarceration on inner city neighborhoods. See Susan Finlay \& Robin E. Wosje, Judges as Change Agents, Nev. LAw., Dec. 2002, at 22 (there are more than 1200 drug courts nationwide); Meares, Norms, supra note 24, at 397 (describing "reverse stings" in Chicago neighborhoods that targeted buyers, mostly white suburban, rather than buyers, who were mostly inner city minorities).

${ }^{215}$ Andrew Taslitz argues that in efforts to address racial inequality in the criminal justice system it is important to organize both communities of color as well as whites. 
entrenched stereotypes about people of color, but particularly African American individuals. Three primary obstacles to changing white perceptions of crime and criminality create significant hurdles to political mobilization. The first is the deeply embedded belief among whites of black criminality. The second is that most whites understand race discrimination to mean intentional actions motivated by a "bad" actor. The third obstacle is the invisibility (to whites) of white privilege that largely protects whites from the excesses of police mistreatment and suspicion.

As Kathryn Russell notes, whites believe both that African Americans are arrested, charged and convicted in numbers disproportionate to their population and that African Americans are responsible for most of the crime. ${ }^{216}$ The first is accurate, the second is inaccurate. ${ }^{217}$ Whites account for sixty-seven percent of all arrests and, in some categories of offenses, whites account for more than eighty percent of all those arrested. ${ }^{218}$ The belief that most crime is committed by African Americans creates a fear of black crime-and particularly violent crime-that is wholly out of proportion to offending data. Yet, as Russell describes, the result of " $[t]$ he public's perception that crime is violent, Black, and male ... [is] to create the criminalblackman." 219 As David Cole notes, "[t]here is a mutually reinforcing relationship between criminal stigmatization of blacks and racial subordination: the criminal stigmatization of blacks perpetuates and justifies their subordination as a group, and the status of blacks as a segregated, subordinated group makes it easier to insist on ever-morestringent stigmatizing measures in the criminal law., 220

The correct belief that African Americans are arrested and incarcerated in disproportionate numbers gives rise to the more questionable belief that they commit crimes in disproportionate numbers. It is this belief that serves to rationalize racial profiling in traffic stop enforcement and searches. ${ }^{221}$

Andrew E. Taslitz, Racial Auditors and the Fourth Amendment: Data with the Power to Inspire Political Action, 66 LAW \& CONTEMP. PROBS. 221, 273 (2003). Taslitz argues that "an express focus on conscious or subconscious racial discrimination in policing is a powerful way to motivate racial minorities as troops in the battle for reforming police search and seizure and excessive force practices." Id. at 273.

${ }^{216}$ RuSSELL, supra note 27, at 111.

${ }^{217}$ Id. Russell notes that two thirds of arrests for street crimes are of whites. Id.

${ }^{218}$ Id. (citing 1995 statistics from Sourcebook of Criminal Justice Statistics (1991-1995), Bureau of Justice Statistics).

${ }^{219}$ RUSSELL, supra note 27, at 114.

${ }^{220}$ COLE, supra note 8 , at 177.

${ }^{221}$ See Harris, supra note 45 , at 78 (describing police officers who argued that racial profiling in traffic stops was justified by the disproportionate numbers of minorities arrested and incarcerated). 
The evidence for differential offending rates is mixed ${ }^{222}$ but as noted earlier, it is particularly weak in the case of drug arrests. ${ }^{223}$ Because "[d]rug offenses are profoundly discretionary in terms of who gets arrested, where police patrol, and in the aggressiveness of police, prosecution, and the sentencing policy that is targeted at drug offenders,"224 there is little reason to believe that arrest and incarceration data reflects actual rates of offending. It is impossible to disentangle differential offending rates from differential enforcement strategies. If African American communities are more heavily policed and African American drivers more frequently stopped and searched, the result will be more African Americans incarcerated, regardless of their comparative offending rates with whites. ${ }^{225}$

In addition to evidence of discriminatory police practices, evidence suggests that African Americans arrested for drug offenses are treated more

${ }^{222}$ See RusSELL, supra note 27, at 27-46. Blumstein reports that for serious non-drug crimes, African Americans make up roughly the same proportion of those arrested as for those imprisoned, suggesting no racial discrimination occurs post-arrest that results in disproportionate imprisonment. Blumstein, Racial Disproportionality, supra note 24, at 748. Blumstein also notes other research demonstrating that for serious interpersonal crimes, the percentage of African Americans arrested corresponds with the percentage identified as perpetrators by victim reports. Id. There remain questions of differential enforcement and differential reporting. Further, Blumstein finds that in the non-drug serious offense cases, there remains twenty percent racial difference in incarceration that is not explained by differences in offending rates. Id. at 749. Russell concludes that "research shows evidence of racial discrimination against Blacks in the criminal justice system and evidence that Blacks disproportionately offend." RuSSELL, supra note 27 , at 30 .

${ }^{223}$ See Blumstein, supra note 24 , at $746-48,750-51$ (with regard to serious non-drug crimes, the fraction of arrests that are African Americans is similar to the fraction incarcerated for the same crime, further, the victim's report of the race of the perpetrator in interpersonal crimes is roughly similar to the race of those arrested for these crimes). Some offending differences may be the product of differences in victim reporting. For example, some research demonstrates that low-income African American women were more likely to call the police in response to a domestic violence incident than were white women with similar incomes or white women with higher incomes. See Ira W. Hutchison \& J. David Hirschel, Abused Women: Help-Seeking Strategies and Police Utilization in VIOLENCE AGAINST WOMEN 436, 452-53 (1998) (reporting that African American low income battered women were more likely to rely on police response than were white low income battered women).

${ }^{224}$ Alfred Blumstein, Mass Incarceration: Perspectives on U.S. Imprisonment, 7 U.CHI. L. SCH. RouNdTABLE 95, 99 (2000).

${ }^{225}$ In addition, as Bernard Harcourt demonstrates, even if it is true that a larger percentage of African Americans commit crimes than is true of other racial groups, where crime is abundant and law enforcement is limited, if police efforts are apportioned in accordance with offending rates, and the same percentages of arrests maintain, the effect over time is to ratchet up the racial disproportionality. Bernard E. Harcourt, From the Ne'erDo-Well to the Criminal History Category: The Refinement of the Actuarial Model in Criminal Law, 66 LAW \& CONTEMP. PROBS. 99, 135 (2003). 
harshly after arrest than are whites. Criminologist Alfred Blumstein reports that while African Americans comprise about forty percent of those arrested for drug offenses, they comprise nearly sixty percent of those serving prison sentences for drug offenses. ${ }^{226}$

Even with regard to those categories of crime where African Americans appear to offend at higher rates, ${ }^{227}$ twenty percent of the race disparities in sentencing remain unexplained by racial differences in offending. ${ }^{228}$ This residual difference of twenty percent represents ten thousand African American prisoners. ${ }^{229}$ As Kathryn Russell notes, "[t]en thousand Blacks who may have been treated more harshly by the criminal justice system because of their race, constitutes an enormous social problem." ${ }^{230}$ Thus, with regard to serious non-drug offenses, there remain a significant number of African American prisoners whose imprisonment may be the result of their race. With regard to drug offenses, there are likely many more African Americans whose imprisonment is a result of their race.

Despite this evidence that a significant portion of racial disparities represents differences in enforcement and differences in treatment, the link in white consciousness between African Americans and criminality remains strong. Andrew Taslitz worries that some education efforts aimed at whites may inadvertently reinforce this connection. ${ }^{231}$ Taslitz points to the arguments made by the executive director of Amnesty International that suggest that one way in which whites are harmed by racial profiling is that it may create racial unrest such as the riots in Los Angeles that followed the acquittal of the police officers who beat Rodney King. ${ }^{232}$ Taslitz worries that this kind of appeal reinforces the idea of African American violence and criminality. ${ }^{233}$

${ }^{226}$ Blumstein, Racial Disproportionality, supra note 24, at 751-52

${ }^{227} \mathrm{Id}$. at 746 (finding that the proportion of arrestees for serious street crime that are African American is similar to the proportion in prison for the same crime categories, thus suggesting that there is no discrimination in the treatment post-arrest). Blumstein cites other research that finds similarities between victim reports of offender race and arrests for the relevant crimes thus suggesting that there is little discrimination in arrest for serious crimes. Id. at 748 (citing Michael Hindelang's research).

${ }^{228}$ Id. at 747 (citing his earlier study, Blumstein concludes that "eighty percent of the [racial] disproportionality in prison was explained just by the differential involvement in arrest").

229 Id. at 747 .

${ }^{230}$ RuSSELL, supra note 27, at 31 . Further, Blumstein's comparison of arrest versus incarceration rates does not address racial differences in sentencing.

${ }^{231}$ Taslitz, supra note 215 , at 276-77.

232 Id. at 276-77.

$233 \mathrm{Id}$. 
Devon Carbado raises a related but different set of concerns. He writes that "the public campaign against racial profiling invariably calls upon notions of innocence." 234 Carbado notes that an ACLU pamphlet on traffic stops and racial profiling features the pictures and personal stories of two "respectable" looking African American victims of profiling. ${ }^{235}$ However, the discussion of the Whren case, which permitted pretextual stops, includes no picture of Whren and provides no personal story. Carbado concludes that Whren was treated in this way because he is not a "respectable" individual; he was a drug possessor. The paradigmatic reform narrative here is one where a "bad" police officer conducts a racebased stop of a "good" African American. ${ }^{236}$ The result, according to Carbado, is that this "good black/bad cop framework ... renders [cases like Whren] difficult to challenge publicly."237 Further, the focus on "good" or "respectable" African Americans may reinforce the idea that these individuals are the exceptions, while most African Americans suspected by the police of criminal misconduct are, in fact, guilty.

The concerns of Carbado and Taslitz are supported by research that demonstrates the difficulty of changing negative racial stereotypes. ${ }^{238}$

${ }^{234}$ Carbado, supra note 97, at 1035.

${ }^{235}$ Id. at 1038.

${ }^{236}$ Id. at 1040-41. Carbado notes that Randall Kennedy's proposal that African Americans adopt a "politics of respectability" is consistent with the manner in which the ACLU pamphlet is written. Id. at 1038-39; see RANDALL KENNEDY, RACE, CRIME AND THE LAW 19-21 (1997). Kennedy argues that "those dedicated to advancing the interests of African Americans ought to urge them to conduct themselves in a fashion that . . . elicits respect and sympathy rather than fear and anger from colleagues of other races." KENNEDY, supra note 237, at 21. Carbado writes that Kennedy fails to recognize the costs of his proposal. One of the costs is to reinforce the notion that there are "good" and "bad" blacks. Carbado, supra note 97, at 1042. Thus,

to the extent that police officers operate under the assumption that part of their law enforcement project is to ferret out the 'good' blacks from the 'bad' blacks, and to the extent that the goodness (noncriminality) of blackness is not assumed but must be demonstrated . . . all black people are vulnerable to racial profiling.

Id. at 1043. Regina Austin notes that this emphasis on "respectability"-what she calls a "politics of distinction"-counters stereotypes of deviance, however, "[o]n the downside [it] ... intensifies divisions .... [and] furthers the interests of a middle class .... The persons who fare best under this approach are those who are the most exceptional (i.e., those most like successful white people)." Regina Austin, "The Black Community," Its Lawbreakers, and the Politics of Identification, 65 S. CAL. L. REV. 1769, 1773 (1992). Angela Harris argues that giving voice to the community in responding to crime offers an alternative that is neither a "politics of identification" with lawbreakers nor is it "politics of distinction" in which lawbreakers should be "cast[] out . . by vigorous law enforcement." Angela Harris, Criminal Justice as Environmental Justice, 1 J. GENDER RACE \& JUST. 1, 3 (1997).

${ }^{237}$ Carbado, supra note 97, at 1040-41.

${ }^{238}$ See Mark Peffley et al., Racial Stereotypes and Whites' Political Views of Blacks in 
However, this research also suggests that the effects of negative stereotypes can be neutralized, at least in the individual case, when stereotypers are confronted with information about an individual that contradicts their negative stereotypes. ${ }^{239}$ A national random survey of whites regarding their attitudes towards race, crime and welfare, conducted by Peffley et al., provides an example. The researchers found that a significant number of whites surveyed believed that African Americans were aggressive or violent and a smaller number believed that they were lazy. ${ }^{240}$ These negative stereotypers responded more punitively to policy questions regarding crime and welfare when the scenario involved African Americans than when the scenario involved similarly described whites. ${ }^{241}$ However, this was only true when African Americans were described in ways that confirmed the lazy or violent stereotypes. ${ }^{242}$ When negative stereotypers were given scenarios in which African Americans were depicted in strongly counterstereotypical ways, they responded more favorably to African Americans then to similarly described whites. ${ }^{243}$ The researchers suggest that whites who hold negative stereotypes of African Americans may simultaneously adhere to "[p]ositive racial subtypes of especially hardworking or wellbehaved blacks ... with subtypes being reserved for the few exceptions that "prove the rule.","244

The ACLU's "Driving While Black/Brown" campaign described by Carbado is an attempt to offer stories that contradict a stereotype of black criminality. The research of Peffley et al., suggests that such a campaign may be successful in encouraging stereotyping whites to believe that an injustice was done in individual cases. The same research, however, suggests that stories that contradict stereotypes may not change a person's belief in the general truth of the stereotype. ${ }^{245}$ Whether a change in the

the Context of Welfare and Crime, 41 AM. J. PoL. SCI. 30, 31 (1997) (describing social cognition literature that describes stereotypes as resistant to change).

${ }^{239} \mathrm{Id}$. at 52 (describing the results of a national random survey undertaken in 1991 to assess the political impact of whites' stereotypes of African Americans). See also John Hurwitz \& Mark Peffley, Public Perceptions of Race and Crime: The Role of Racial Stereotypes, 41 AM. J. POL. ScI. 375, 380 (1997) (describing the results of a similar research design in a study of white attitudes in Lexington, Kentucky and finding the same results).

${ }^{240}$ Peffley et al., supra note 238, at 35 ("whites agreeing that most blacks are lazy (31\%), irresponsible (20\%), aggressive [or violent] $(50 \%)$, and lacking in discipline $(60 \%)$ ).

241 Id. at 52 .

$242 I d$.

${ }^{243} \mathrm{Id}$.

244 Id.

${ }^{245} I d$. at 53. 
stereotype occurs is likely to be related, in part, to the frequency with which stereotyping whites are confronted with such counter-stereotype stories. ${ }^{246}$

The second obstacle to changing white consciousness regarding crime and racial disparities in the criminal justice system is that most whites understand racism to refer to the intentional conduct of a person who is motivated by racial hatred. ${ }^{247}$ Not only must there be a victim-preferably a worthy or "innocent" victim-but there must also be a villain. ${ }^{248}$ This perception means that stories of racial injustice in the criminal justice system seldom address either systemic privileging of whites over people of color $^{249}$ or unconscious racial stereotyping. ${ }^{250}$

While some police and prosecutors operate with intentional racial malice, many do not. Even in drug enforcement, where there is much discretion, law enforcement officers and prosecutors may intend to make choices that are not related to race. So, for example, when a police officer was shown data that in his district African Americans were much more frequently targeted for narcotics warrants than were whites or Latinos, he responded by saying, "we go where the work is."251 Despite evidence that race-based stops are less likely to uncover contraband than are stops based on race-neutral factors, ${ }^{252}$ some police officers continue to believe that racebased stops are simply efficient policing. ${ }^{253}$

A narrative that permits a discussion of racism only if there are intentionally racist police officers or prosecutors, will place whites in a

${ }^{246}$ Id. The researchers conclude that "[s]tereotype inhibition requires sufficiently powerful and plentiful contrary examples so that [stereotyping] whites have enough anecdotes in their minds that problems such as . . . crime do not immediately and automatically suggest the involvement of African Americans." Id.

${ }^{247}$ RUSSELL, supra note 27, at 111; Martha Mahoney, Class and Status in American Law: Race, Interest, and the Anti-Transformation Cases, 76 S. CAL. L. REv. 799, 809 (2003) ("[M]ost whites understand racism as something that a second party does to or believes about a third party. The second party is the bad racist actor, and the third party the subordinated person of a minority race-both are distinguished from the way whites understand themselves.").

${ }^{248}$ See Mahoney, supra note 247, at 809 . Whites understand racism as something a "bad racist actor" does to a "person of a minority race--both are distinguished from the way whites understand themselves." Id.

${ }^{249}$ Stephanie M. Wildman et al., Privilege Revealed: How Invisible Preference UNDERMINES AMERICA 12 (1996) ("'Racism' is defined by whites in terms of specific, discriminatory racist actions by others.").

${ }^{250}$ Charles R. Lawrence, The Id, the Ego, and Equal Protection: Reckoning with Unconscious Racism, 39 STAN. L. REV. 317 (1987) (much of racial discrimination will not be addressed by law that requires proof of intentional acts because racism is often unconscious).

${ }^{251}$ Benner, supra note 26, at 200.

${ }^{252}$ See Harris, supra note 45, at 82.

${ }^{253}$ Id. at 78. 
bind. Most whites reject the idea that they are racist. ${ }^{254}$ Therefore, they must either view these officers and prosecutors as different from themselves-that is, as "bad racist actors"255 —or they must conclude that, because criminal justice actors were not motivated by racial animosity, the actions were not "racist." If the actions were not "racist," there is no "race problem."

The third problem for confronting white complacency (or encouragement) of race disparities in the criminal justice system is the invisibility (to whites) of white privilege. Whites seldom think of themselves through the lens of race; whiteness is invisible to most whites. ${ }^{256}$ Rather, whites see themselves and other whites as individuals. ${ }^{257}$ Because they cannot see the privilege that protects them from police maltreatment and suspicion, they have difficulty believing that such treatment is not in some way invited or provoked when it happens to others. ${ }^{258}$ Surveys show that the majority of whites do not believe that African Americans receive harsher treatment in the criminal justice system, ${ }^{259}$ and when asked about their local police officers, large majorities of whites express confidence in the ability of local police to treat African Americans and whites equally. ${ }^{260}$

Of course, white privilege does not render every white immune from police mistreatment or suspicion. There are whites whose presence is considered suspect by "respectable" whites. "Respectability" allows whites to avoid this categorization, however. As a number of racial profiling incidents illustrate, respectability does not offer similar protection for African American individuals. ${ }^{261}$ In fact, research finds that socio-

${ }^{254}$ See Wildman, supra note 249 , at 11 ("[C]alling someone a racist . . lays the blame on the individual rather than the systemic forces that have shaped that individual and his or her society. White people . . become concerned with how to avoid [the racist] . . label, rather than worrying about systemic racism ....").

${ }^{255}$ Mahoney, supra note 247, at 809.

${ }^{256}$ See generally Barbara J. FLAGG, White CONSCIOUSNESS AND THE LAW: WAS BLIND BUT NOW I SEE (1998); Wildman, supra note 249.

257 See Mahoney, supra note 247 , at 810 (describing the way affirmative action programs "change[] the transparent quality of whiteness" by forcing whites to "identify as white rather than as individuals with no race.").

${ }^{258}$ See, e.g., Taslitz supra note 6, at 278-79 (Whites who believe in black criminality may believe that illegal stops of African Americans are the fault of African Americans and if they consider the person stopped to be "blameworthy," they may react with anger towards the victim of the racial stop.).

259 See, e.g., Ronald Weitzer \& Steven A. Tuch, Race, Class, and Perceptions of Discrimination of Police, 45 CRIME \& DeLINQ. 494, 498 (1999).

260 Id.

${ }^{261}$ See, e.g., Carbado, supra note 97, at 1043 (noting that the politics of respectability does not protect "good" blacks). 
economic status does not insulate African Americans from racial profiling. ${ }^{262}$ Color "trumps" respectability.

There are many efforts underway to change the race disparities in the criminal justice system. In the next section I examine the potential of the growing "Innocence Movement" to act as a vehicle for shifting white perceptions in ways that encourage whites to challenge the differential treatment of African Americans and Latinos in the criminal justice system. The Innocence Movement is not generally understood to focus on racial injustice, but I argue that while the movement has limitations, it can nevertheless be harnessed as an effective vehicle for pursuing a racial justice agenda.

\section{B. THE INNOCENCE MOVEMENT}

When I speak of "The Innocence Movement" I refer to the work of lawyers and non-lawyers on behalf of persons convicted of crimes they did not commit. Religious organizations, attorneys and scholars have pursued this work for some time, but the momentum giving rise to over 136 exonerations ${ }^{263}$ can be traced largely to the work of the Innocence Project begun by Berry Scheck and Peter Neufeld at Cardozo Law School. ${ }^{264}$ The Innocence Network, initiated by Cardozo and Northwestern law schools, ${ }^{265}$ is a network of projects in thirty one states, ${ }^{266}$ involving law schools as well as individual attorneys. ${ }^{267}$

${ }^{262}$ Weitzer \& Tuch, supra note 259, at 503 (noting that research finds that four out of ten African Americans, irrespective of middle-class status, had personal experience of police mistreatment, while very few whites had such experiences).

${ }^{263}$ See Cardozo Innocence Project at http://www.innocenceproject.org (last visited Oct. $14,2003)$. Others proffer much higher numbers. See, e.g., Website of Dr. Edmund Higgins at http://www.dredmundhiggins.com/database.htm (last visited Oct. 14, 2003) (database of all wrongful convictions in Canada and U.S.; includes 316 cases).

${ }^{264}$ See SCHECK ET AL., supra note 71 , at 323 for a description of the origin of this project. ${ }^{265} \mathrm{Id}$. at 323.

${ }^{266}$ The network is "a group of law schools, journalism schools, and public defender offices across the country that assists inmates trying to prove their innocence ...." $\mathrm{http}: / / \mathrm{www}$.innocenceproject.org/about/index.php. The Innocence Project at http://www.innocenceproject.org/about/other projects.php (last visited Oct. 14, 2003) (listing the projects by state).

${ }^{267}$ Id. Many law schools have adopted innocence projects. See, e.g., Cardozo Innocence Project, supra note 263 (recently achieving its $138^{\text {th }}$ exoneration); Innocence Project New Orleans at http://www.ip-no.org/index.html (last visited Oct. 14, 2003); Innocence Project of the National Capital Region at http://www.wcl.american.edu/innocenceproject/ (last visited Oct. 14, 2003); The North Carolina Center on Actual Innocence at http://www.law.duke.edu/ innocencecenter/ (last visited Oct. 14, 2003). Notable individuals have appeared publicly to talk about the problem of wrongful convictions and to urge prosecutorial reform to prevent such occurrences. See Press Release, The Plight of the Wrongfully Convicted Takes Center 
The movement has had an impact on shaping public awareness of the fallibility of the criminal justice system. This public recognition has likely had the most significant impact on destabilizing support for the death penalty. This effect can be seen from the mass commutations made by former Governor George Ryan of Illinois, ${ }^{268}$ to the Supreme Court's recent decision that it is unconstitutional to execute mentally retarded individuals ${ }^{269}$ to the introduction of federal legislation for a moratorium on federal death penalty prosecutions. ${ }^{270}$

In 2000, Scheck and Neufeld analyzed seventy-four exoneration cases. In each of these cases, DNA evidence cleared the person initially convicted of the crime. ${ }^{271}$ Scheck and Neufeld determined that the following factors contributed to wrongful convictions in those cases: mistaken eyewitness testimony $(82 \%)$; police misconduct $(50 \%)$; prosecutorial misconduct $(45 \%)$; inadequate defense counsel (32\%); false confessions ( $22 \%)$; snitches

Stage at the University of Miami, available at http://www.wrongfulconvictions.com/ releases.htm (last visited Oct. 14, 2003).

${ }^{268}$ See Governor George Ryan, Address at Northwestern University College [sic] of Law (Jan. 11, 2003) available at http://www.cuadp.org/20030111ryan.html (noting the importance of the work of those working to exonerate innocent prisoners, as well as the work of individuals who represent those charged with capital offenses).

${ }^{269}$ Atkins v. Virginia, 536 U.S. 304 (2002). The Court noted that mentally retarded individuals may be at greater risk of wrongful conviction because they are more likely to make false confessions and are unable to assist their counsel. Id. at 320-21. This point was argued by a number of amici as well as the defendant. See Brief of Amici Curiae of the A.B.A. in Support of Petitioner at 14, Atkins v. Virginia, 536 U.S. 304 (2002) (No. 00-8452) [hereinafter "ABA brief"] (describing cases of mentally retarded individuals convicted and sentenced to die for crimes they did not commit); Brief of Amici Curiae of the Am. Civil Liberties Union, et al., at 2, Atkins v. Virginia, 536 U.S. 304 (2002) (No. 00-8452) [hereinafter "ACLU Brief"] ("the unique challenges presented by death penalty cases involving persons with mental retardation have resulted in serious obstacles to fair ... treatment for this class of imprisoned people who are at special risk of unjust punishment"). Amici highlighted the stories of Earl Washington and Anthony Porter, two mentally retarded prisoners convicted of capital crimes, who were later exonerated. ACLU Brief at 7-8, Atkins (No. 00-8452); ABA Brief at 14-15, Atkins (No. 00-8452). Washington was sentenced to death in Virginia based on his confession, but was later cleared by DNA evidence. ACLU Brief at 7, Atkins (No. 00-8452). Porter was within days of being executed when journalism students at Northwestern conclusively demonstrated that he had not committed the crime. Jon Jeter, A New Ending to an Old Story: Journalism Students Rewrite the Case of an Innocent Man Set to Die, WASH. POST, Feb. 17, 1999, at C01. Erwin Chemerinsky points out that Atkins "is the first Supreme Court case that has paid a great deal of attention to the need to administer the death penalty in a manner that minimizes the likelihood of executing an innocent person." Erwin Chemerinsky, Supreme Court Review, 51 U. KAN. L. REV. 269, 274 (2003).

${ }^{270}$ The National Death Penalty Moratorium Act of 2001, S. 233, 107th Cong. (2001). The Act was introduced by Senator Russell Feingold.

271 SCHECK ET AL., supra note 71, at 318. 
or informants $(19 \%) .{ }^{272}$ In addition, one third "involved tainted or fraudulent science." more troubling findings is that several of these factors are more pronounced in the conviction of innocent black men., 274

Many of the widely publicized cases of wrongful conviction involved African American inmates. ${ }^{275}$ The Innocence Project's review of exonerations in 2000 found that fifty-five percent of exoneration cases involving sexual assaults or murders involved African American male defendants and white victims. ${ }^{276}$ This rate is four times the rate at which African Americans are charged with killing or raping white victims, ${ }^{277}$ suggesting that these kinds of cases may be particularly prone to wrongful conviction.

Despite these facts, and the fact that one chapter of Scheck and Neufeld's book is devoted to "race" as a cause of wrongful conviction, little of the public awareness of the Innocence Movement or of the exoneration cases focuses on racism as a central cause of conviction of the innocent. ${ }^{278}$ Bryan Stevenson argues that the tolerance of race bias in the operation of the criminal law increases the risk of wrongful convictions for African Americans suspected or accused of crime. ${ }^{279} \mathrm{He}$ also argues that the significant racial disparities in drug arrests has fueled the "presumption of criminality" regarding African Americans. ${ }^{280}$

${ }^{272} \mathrm{Id}$.

${ }^{273} \mathrm{Id}$.

${ }^{274}$ Id.

${ }^{275}$ See, e.g., Frontline, Requiem for Frank Lee Smith at http://www.pbs.org/wgbh/ pages/frontline/shows/smith/ (last visited Oct. 14, 2003) (describing the case of a Florida inmate exonerated by DNA after his death in prison of cancer); SCHECK ET AL., supra note 71.

${ }^{276}$ SCHECK, ET AL, supra note 71, at 265.

277 Id.

${ }^{278}$ A few scholars have examined the effect of race as a cause of wrongful conviction. See, e.g., Karen F. Parker et al., Race, the Death Penalty and Wrongful Convictions, 18 CRIM. JUST. 49, 49-51 (2003) (recounting research findings that African Americans are more likely to be wrongly convicted); see generally Arthur L. Rizer III, The Race Effect on Wrongful Convictions, 29 WM. MITCHELL L. REv. 845 (2003).

${ }^{279}$ Bryan Stevenson, Transcript of Innocence and Race, Lecture Recorded for Innocence Project at 5, available at http://www.innocenceproject.org/about/course.php (DVD and transcript available from website) [hereinafter Stevenson Transcript]. The Innocence Project, the Center on Wrongful Convictions at Northwestern University, and The Innocence Network, developed a wrongful conviction course. Stevenson's lecture is one of thirteen lectures recorded on CDs for use in the course. Stevenson is one of the lecturers. See also Bryan A. Stevenson \& Ruth E. Freedman, Deliberate Indifference: Judicial Tolerance of Racial Bias in Criminal Justice, 51 WASH. \& LEE L. REV. 509 (1994).

${ }^{280}$ Stevenson Transcript, supra note 279, at 6. 
Activists have argued for a number of reforms designed to address the list of problems that give rise to wrongful convictions. Many, if not all, of these reforms would benefit, and benefit disproportionately, African Americans. ${ }^{281}$ For example, cross-racial identifications are particularly unreliable. ${ }^{282}$ The recommendation by Innocent Movement activists that identification lineups or photos be done sequentially rather than simultaneously, ${ }^{283}$ if adopted, would likely decrease the chance that a white witness will misidentify an African American suspect simply because "they all look alike." Similarly, the recommendation that to avoid false or coerced confessions, all interrogations be videotaped or at least audio taped ${ }^{284}$ may diminish the use of coercive police techniques and physical torture, tactics reported by a number of African American exonerees. Reform recommendations aimed at making police and prosecutor decisions more public and more open to scrutiny, if adopted, would benefit individual African Americans suspected of criminal activity by diminishing police and prosecutor misconduct. ${ }^{285}$ The recommendations for increasing the quality of criminal defense representation for the poor-increased funding, reasonable case loads, adequate training and appropriate standards of competency-would assist African Americans charged with criminal offenses, who are disproportionately low-income. ${ }^{286}$

${ }^{281}$ Many of the widely publicized cases of wrongful conviction involved African American prisoners. See, e.g., Frontline, The Case for Innocence at http://www.pbs.org/ wgbh/pages/frontline/shows/case/ (last visited Oct. 14, 2003) (discussing wrongful convictions, including the case of Earl Washington, broadcast in the documentary aired on Public Broadcasting Network); SCHECK ET AL., supra note 71, at 339-40 (describing the Washington case).

${ }^{282}$ ElizABeTH F. LofTus, Eyewitness Testimony 136-42 (1979) (noting that subjects recognized members of their own race more easily than members of a different race). Several of the exonerations involved cross-racial identifications. See SCHECK ET AL., supra note 71, at 255 (describing the case of Calvin Johnson, an African American convicted of rape of a white woman for whom DNA evidence later exonerated; Johnson was identified in a photo lineup by a white rape victim).

${ }^{283}$ See SCHECK ET AL., supra note 71, at 351-52.

${ }^{284} \mathrm{Id}$. at 352.

${ }^{285}$ See, e.g., SCHECK ET AL., supra note 71, at 353-54 (urging use of independent crime labs); id. at 355 (urging development of separate disciplinary committees to deal exclusively with allegations of prosecutorial and police misconduct); id. at 357 (urging the establishment of innocence commissions). As David Cole notes, the current system operates with a formal norm of transparency, but with a hidden norm of secrecy. COLE, supra note 8, at 186

${ }^{286}$ See generally Stephen G. Bright, Glimpses at a Dream Yet to be Realized, CHAMPION, Mar. 22, 1998, at 12 (noting that representation for poor criminal defendants is often inadequate). 
Though this list of reforms would assist individual African Americans suspected or accused of a crime, the list does not include reforms that explicitly address the manner in which racial stereotypes lead to the conviction of the innocent. Stevenson argues that students and lawyers working for innocence projects must confront the impact of race on wrongful convictions. ${ }^{287} \mathrm{He}$ concludes that this requires "a broader vision of what equal justice requires" ${ }^{\text {"28 }}$ then improving forensic science or increasing access to competent counsel. ${ }^{289}$

There are at least three ways in which the Innocence Movement may be useful as a vehicle for changing white perceptions regarding crime, black criminality, and the criminal justice system. First, by challenging white faith in the fairness and accuracy of the criminal justice system, the movement challenges the belief that those whom criminal justice actors suspect or mistreat deserved or provoked such treatment. Exoneration stories often involve individuals with criminal histories and thus illustrate the problem with presuming guilt on the basis of criminal history or "unrespectable" appearance. ${ }^{290}$ They do not tell the narrative of "bad" officer and "good" African American individual that Carbado describes in the Driving While Black/Brown campaign literature. ${ }^{291}$ Therefore, these narratives about exonerees have the potential to demonstrate the harms that racist practices create for those who are not "angels.",292

The second way in which the Innocence Movement may help to change white perceptions is to challenge presumptions of black criminality. Exoneration cases present an alternative explanation for racial disparities in arrest and sentencing. Exoneration cases suggest that some of this disparity is due to police or prosecutorial misconduct, rather than to racial differences in rates of offending.

Finally, a focus on the cases of police and prosecutorial misconduct leading to the conviction of the innocent, may provide a way of talking about the harms that flow from misconduct in the cases of the "guilty." The accused who receives a longer sentence because the officer lied is no less the victim of misconduct than the person who did not commit a crime at all.

${ }^{287}$ Stevenson Transcript, supra note 279, at 13.

${ }^{288} \mathrm{Id}$.

${ }^{289} \mathrm{Id}$.

${ }^{290}$ See, e.g., Jeter, supra note 269 (describing the exoneration of Porter, noting that when Porter was arrested for the homicide he had been arrested nearly two dozen times and convicted of armed robbery).

${ }^{291}$ See Carbado, supra note 97, at 1038.

292 Jeter, supra note 269 (referring to Porter, exonerated in a homicide; Jeter notes that Porter "was no angel"). 
Despite these potential uses of the Innocence Movement, there are several possible limitations. The Innocence Movement discourse focuses on individual bad actors-police officers or prosecutors who engage in misconduct and forensic experts who lie. This discourse is not focused on systemic questions regarding law enforcement priorities: where to concentrate enforcement efforts; who should be the focus of search warrants; who should be charged; and what charges should be brought. As described earlier, these questions are key in challenging racial disparities in drug enforcement arrests. In addition, a focus on innocence may detract from the injustices that are routinely visited on the "guilty."293 The focus on the few who can demonstrate actual innocence should indict the entire system, but not surprisingly, we hear defenders of the system declare that the increased availability of DNA evidence and the fact that mistakes have been found means that the criminal system is working! ${ }^{294}$ In fact, in a number of cases, prosecutors continued to oppose the release of individuals whom DNA evidence proved did not commit the crime. ${ }^{295}$

Another limitation of the Innocence Movement may be the lack of emphasis placed on the mental state of the accused. Criminal responsibility generally requires both that an individual engage in the conduct prohibited by law (or assist another in so doing) and that the person have the requisite mental state (the mens rea) that renders it fair to hold him or her accountable for the conduct.

Innocence discourse, like innocence cases, tends to focus on actus reus questions. The claim, by its nature, is almost always one of mistaken identity: I did not do the act for which I am accused. A focus that equates "innocence" with not having engaged in the proscribed conduct may encourage the public to view mental states as mere technicalities unrelated to real innocence. Yet, the effect of racism may be profound in those cases that turn on mens rea questions. For example, research suggests that whites are more likely to view African American defendants as dangerous and violent than they view white defendants. ${ }^{296}$ If this is the case, we would

${ }^{293}$ See generally David Feige, The Dark Side of Innocence, N.Y. TIMES MAG., June 15, 1993 , at 15 .

${ }^{294}$ See, e.g., Martin J. Oberman \& Kathleen L. Roach, Justice Denied, CHI. TrIB., Nov. 1, 1997, at 21. Illinois Governor Jim Edgar, in response to seven exonerations among death row inmates, described the exonerations as the justice system working as it should. Id.

${ }^{295}$ See SCHECK ET AL., supra note 71.

${ }^{296}$ See, e.g., Joshua Correll et al., The Police Officers's Dilemma: Using Ethnicity to Disambiguate Potentially Threatening Individuals, 83 J. PERS. \& SOC. PSYCHOL. 1314, 1325 (2002). Subjects who were asked to shoot a video image if the person displayed was carrying a gun, "use[d] ethnicity to interpret an ambiguously threatening target" resulting in more accurate targeting of African Americans when the decision was to shoot and more 
expect that white jurors are more likely to disbelieve claims of African Americans that depend on proving that the defendant was fearful or coerced-mental states necessary for self-defense and duress. Presumptions of black criminality may also encourage white jurors to doubt the veracity of testimony that contradicts racial stereotypes. So, we might expect white jurors to disbelieve African American defendants who claim they did not enter into a criminal agreement or that they did not intend to assist another individual to commit a crime. Further, in cases where an African American man is charged with a sexual offense against a white woman, white jurors may be less inclined to believe a defendant's testimony that the woman consented to sexual relations.

Finally, a focus on the "innocent" may minimize the importance of official misconduct in the cases where the defendant may be guilty of a lesser crime than the one for which he was convicted. Some research finds racial effects in sentencing: African American defendants receive longer sentences than do whites who are convicted of the same crime and who have similar criminal histories. ${ }^{297}$ These cases of "over-incarceration" or "wrongful sentencing" create real harms for individuals, families, and communities, ${ }^{298}$ but a focus on innocence may make these harms appear less important.

accurate decisions not to shoot for white targets. $l d$.

297 See David B. Mustard, Racial, Ethnic, and Gender Disparities in Sentencing: Evidence from the U.S. Federal Courts, 44 J. L. \& ECON. 285, 311-12 (2001). A study of federal sentencing comparing African American, Hispanic, and white defendants who were sentenced in the same district, committed the same offense, and had the same criminal history and offense level. Id. at 300. The study found that African American and male defendants receive longer sentences than do whites for the same crime, are less likely to receive no prison term when that option is available, are more likely to receive upward departures, and less likely to receive downward departures. Id. at 311-12. See also Cassia C. Spohn, Thirty Years of Sentencing Reform: The Quest for a Racially Neutral Sentencing Process, in 3 National Institute of Justice, Policies, Processes, and Decisions of THE CRIMINAL JUSTICE SYSTEM 427, 443 (2000) available at http://www.ncjrs.org/ criminal_justice2000/vol_3/03front.pdf. Spohn reviewed more than forty recent studies on race and sentencing and concluded:

Black and Hispanic offenders-and particularly those who are young, male, or unemployed-are more likely than their white counterparts to be sentenced to prison; they also may receive longer sentences that similarly situated white offenders. Other categories of racial minorities-those convicted of drug offenses, those who victimize whites, those who accumulate more serious prior criminal records, or those who refuse to plead guilty or are unable to secure pretrial release-also may be singled out for more punitive punishment.

Id. at 481 .

298 See supra notes 68-96 and text accompanying (discussing the harms of concentrating incarceration in neighborhoods). 


\section{CONCLUSION}

Former Illinois Governor George Ryan described his decision to commute the sentences of all death row inmates in Illinois in the following way:

I started with this issue concerned about innocence. But once I studied, once I pondered what had become of our justice system, I came to care above all about fairness .... The facts I have seen in reviewing each and every one of these cases raised questions not only about the innocence of people on death row, but about the faimess of the death penalty system as a whole. ${ }^{299}$

Ryan's change in perception offers hope that the Innocence Movement can expand whites' perceptions of racial injustice to move from a concern about "innocence" to a concern about "fairness."

Justice Kennedy's address to the American Bar Association ${ }^{300}$ this summer was both an encouraging and a frustrating sign. Kennedy declared that "[o]ur resources are misspent, our punishments too severe, our sentences too long." ${ }^{301}$ It was encouraging to hear a Justice of the Supreme Court address the issue of massive incarceration as well as the racial disparities in incarcerated persons. ${ }^{302}$ Kennedy deplored the cost of such massive incarceration both in terms of money spent and in terms of human suffering. ${ }^{303} \mathrm{He}$ criticized federal sentencing guidelines and federal mandatory minimum sentences ${ }^{304}$ for the increase in incarceration and for placing too much discretion in the hands of prosecutors. ${ }^{305} \mathrm{He}$ urged the Bar to "help start a new public discussion about the prison system[,]"306 to urge repeal of mandatory minimums, ${ }^{307}$ and to recommend that the pardon process be "reinvigorated." 308

But Kennedy's speech was frustrating for its restatement of the Court's view with regard to the many constitutional challenges, including those that

${ }^{299}$ Ryan Address, supra note 268.

300 Justice Anthony M. Kennedy, Address at the A.B.A. Association Annual Meeting (August 9, 2003) available at http://www.supremecourtus.gov/publicinfo/speeches/sp_0809-03.html (Revised Aug. 14, 2003).

${ }^{301}$ Id.

${ }^{302} \mathrm{Id}$. (noting that of the 2.1 million people who are incarcerated in the U.S., forty percent of those in prisons are African American, ten percent of African American men in their mid-to-late twenties are behind bars, and "[i]n some cities more than $50 \%$ of young African-American men are under the supervision of the criminal justice system").

${ }^{303}$ Id.

${ }^{304}$ Id.

305 Id.

${ }^{306} I d$.

${ }^{307} \mathrm{Id}$.

${ }^{308}$ Id. 
allege racial bias, to the actions of criminal justice personnel: "[i]t is a grave mistake to retain a policy because a court finds it unconstitutional. . . A A court decision does not excuse the political branches or the public from the responsibility for unjust laws." ${ }^{\text {,309 }}$

The Supreme Court is unlikely to be moved to action by increasing evidence of racial disparities or evidence of the harms of those disparities. The democratic process seems the primary avenue available for changing law enforcement priorities that reflect and maintain "seeing crime in shades of Black." ${ }^{310}$ Political support for change requires, in part, addressing white complacency and support for racial injustice in the criminal justice system. In this effort, the Innocence Movement may play a useful role, but only if the discourse of the movement engages race directly as both a source of wrongful conviction and as a source of "over incarceration" or "wrongful sentencing."

309 Id.

310 RUSSELL, supra note 27 , at 110 ("A person would have to live as a hermit to avoid seeing crime portrayed in shades of Black."). 